$$
\text { UNIVERSIDADE DE SÃO PAULO }
$$

PROGRAMA DE PÓS-GRADUAÇÃO INTERUNIDADES EM ENSINO DE CIÊNCIAS

DANILO MENDES VIEIRA

\title{
Interpretando a física: o Role Playing Game (RPG) como forma de explorar problemas abertos
}

Orientador: Prof. Dr. André Machado Rodrigues

São Paulo 


\title{
DANILO MENDES VIEIRA
}

\section{Versão Corrigida}

A versão original se encontra disponível tanto na Biblioteca da Unidade que aloja o Programa de Pós-Graduação quanto na Biblioteca Digital de Teses e Dissertações da USP (BDTD)

\section{Interpretando a física: o Role Playing Game (RPG) como forma de explorar problemas abertos}

\author{
Dissertação apresentada ao Programa de Pós- \\ Graduação Interunidades em Ensino de Ciências da \\ USP, nível mestrado, como requisito para o título de \\ mestre em Ensino de Ciências.
}

Área de concentração: Ensino de física.

Orientador: Prof. Dr. André Machado Rodrigues.

São Paulo 
Autorizo a reprodução e divulgação total ou parcial deste trabalho, por qualquer meio convencional ou eletrônico, para fins de estudo e pesquisa, desde que citada a fonte.

\section{FICHA CATALOGRÁFICA}

\section{Preparada pelo Serviço de Biblioteca e Informação \\ do Instituto de Física da Universidade de São Paulo}

Vieira, Danilo Mendes

Interpretando a física: o Role Playing Game (RPG) como forma de explorar problemas abertos. São Paulo, 2019.

Dissertação (Mestrado) - Universidade de São Paulo. Faculdade de Educação, Instituto de Física, Instituto de Química e Instituto de Biociências.

Orientador: Prof. Dr. André Machado Rodrigues

Área de Concentração: Ensino de Física.

Unitermos: 1. Física - Estudo e ensino; 2. Jogos pedagógicos; 3. Ensino médio. 
Dedico este trabalho aos estudantes que participaram das aplicações do RPG. Muito obrigado por tudo, sem vocês a pesquisa não seria possível. 


\section{AGRADECIMENTOS}

Ao meu orientador, o professor André Machado Rodrigues pelos aprendizados, discussões e ensinamentos que me proporcionou e a paciência que teve durante todo o trabalho.

Ao professor Cristiano Rodrigues de Mattos, pela ajuda com as questões de pesquisa e pelas dicas valiosas.

Aos professores Alexsandro Pereira de Pereira e Paulo Henrique Dias Menezes por participarem da minha banca de qualificação e contribuírem com apontamentos e sugestões que foram muito importantes para a conclusão desta dissertação.

Novamente ao professor Alexsandro Pereira e ao professor Luis Paulo de Carvalho Piassi pelas ótimas arguições no meu processo de defesa de mestrado. Agradeço imensamente aos professores por participarem de forma tão frutífera dessa etapa importante da minha trajetória acadêmica.

Ao Programa de Pós-Graduação Interunidades e seus funcionários, pela oportunidade de realização do curso de mestrado e da minha dissertação.

Ao professor Vitor Fabrício, por todo o apoio durante a aplicação na escola Dona Ana Rosa de Araújo e pelas as conversas sobre jogos e ensino.

À minha companheira Raphaella Padulla, por todo amor, carinho e força que me deu por toda essa jornada. Seu apoio foi imprescindível para que eu tivesse a capacidade de finalizar o presente trabalho.

Aos meus amigos, acadêmicos e companheiros de dia a dia Arthur, Nina e Raul. A ajuda de vocês neste trabalho não é mensurável. Obrigado por todas as conversas sobre a pesquisa, a vida e por sempre serem tão maravilhosos na convivência diária.

Aos amigos do grupo Ecco, especialmente Lucas, Maurício Correa, Taynara e Walter por toda a ajuda durante a pesquisa. 
Aos amigos rpgistas André Bogaz, Camila Morais, Daniel Aidar, Elion Hack, Paulo Galina, Rafael "Divino" Silva, Rafael Miller e Thiago Oliveira pelas constantes e frutíferas discussões sobre o nosso jogo preferido e a interseção com a educação.

Aos amigos da física Bianca, Maurício Abreu, Pedro Oliveira, Rafael Escudeiro, Renato Vasconcelos, Rodrigo Kakunaka, Rodrigo Kurosawa, Rosana Della Bruna e Thales Borrely, pelo apoio e momentos de alegria que me proporcionaram por todos esses anos.

Aos amigos e companheiros desde o tempo do colegial Daniela Takeda, Giorgia Gatti, José Caetano, Liliane Santana, Raphael Amário, Rafael Pereira e Rafael Paiola por todo amor e alegria que me proporcionaram por todos esses anos que nos conhecemos.

Aos amigos Daniela Carrete, Caio, Pedro Lopes, Tiago Miranda e Valeria Lopes pelos ótimos conselhos sobre a pesquisa e a escrita, pelos momentos de diversão e as ótimas conversas.

À minha mesa de RPG e companhia de jogos virtuais Aline, Gabriel, Johann, Juan e Raphaella. Obrigado por toda alegria e diversão que me proporcionam. Que bons dados rolem para vocês para todo o sempre.

A todos de minha família, especialmente minha mãe, Maria de Jesus, meu pai, Ademilton e minha tia, Maria José. Obrigado por todo carinho, amor e estarem sempre presentes para me ajudar.

À Coordenação de Aperfeiçoamento de Pessoal de Nível Superior (CAPES), pela concessão da bolsa de mestrado e pelo apoio financeiro para a realização desta pesquisa. 


\section{Lista de figuras}

Figura 1 - Desenho feito pela estudante Gabriella sobre a aventura..............................................59

Figura 2 - Ficha da personagem Latrima, parte da história/aspectos................................................60

Figura 3 - Ficha da personagem Latrima, parte das perícias, façanhas e equipamentos..................61

Figura 4 - Ficha do personagem Santos Dumont da estudante Vanessa..........................................68

Figura 5 - Desenho simples das naves, feito pelo mestre para exemplificar aos jogadores............69 


\section{Sumário}

Lista de figuras .......................................................................................................................................................... 6

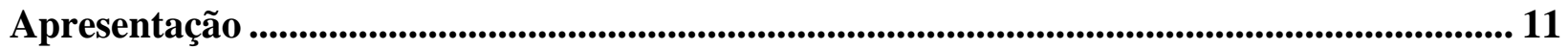

1. Introdução _............................................................................................................................................... 13

2. Objetivos ........................................................................................................................................................ 18

3. Referencial Teórico..................................................................................................................................... 19

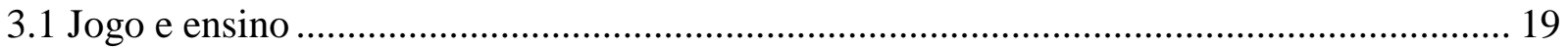

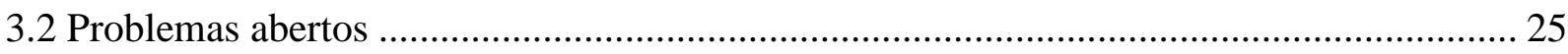

4. Metodologia de pesquisa................................................................................................................................. 34

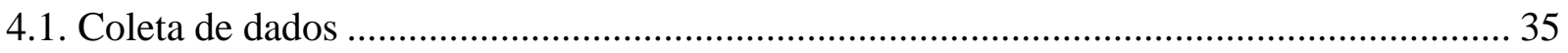

5. Elaboração e execução do jogo ………………………........................................................................ 38

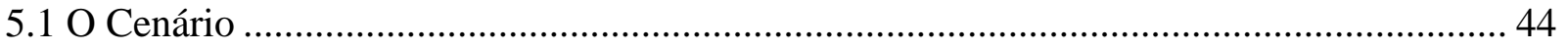

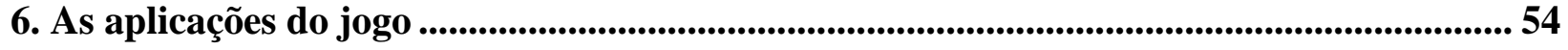

6.1 Descrição e análise dos áudios da segunda aplicação ........................................................... 62

7. Considerações finais........................................................................................................................................ 81

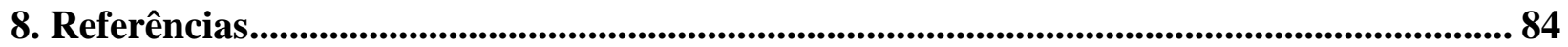


"All in the game yo! All in the game."

Omar Little, The Wire 


\section{RESUMO}

VIEIRA, D. M. Interpretando a física: o Role Playing Game (RPG) como forma de explorar problemas abertos. 2019. 86 f. Dissertação (Mestrado) - Programa de Pós-Graduação Interunidades em Ensino de Ciências - Universidade de São Paulo, São Paulo, 2019.

Esta pesquisa propõe a investigação do uso do Role Playing Game (RPG) no contexto educacional, como uma forma de facilitar o aprendizado de Física para os estudantes. O pressuposto principal para o uso do RPG é que ele pode funcionar como um ambiente para um ensinar física através de problemas abertos. Os problemas abertos são situações que necessitam de soluções, mas os indivíduos envolvidos não conhecem meios ou caminhos evidentes para obtê-las. Eles são úteis na física para conhecer para se conhecer as concepções dos alunos sobre conceitos estruturados cientificamente e também trabalhar significações diferentes dos problemas de lápis e papel. Foi elaborada uma aventura no sistema FATE. Este sistema genérico apresenta regras simples e facilita o processo de iniciação dos alunos ao RPG. Foram realizadas duas aplicações do RPG em contexto educacional, com estudantes em diferentes situações de ensino. Conclui-se que o RPG pode ser proveitoso como uma atividade paralela às aulas tradicionais e como um incentivador da problematização dos conceitos físicos para os alunos.

Palavras-chave: Jogos e educação, Ensino de Física, RPG, Role Playing Game. 


\begin{abstract}
VIEIRA, D. M. Playing physics: the Role Playing Game (RPG) as a way to explore ill-structured problems. 2019. 86 f. Dissertation (Master's Degree) - Science Teaching Interunits PostGraduation Program - Universidade de Sao Paulo, Sao Paulo, 2019.

This research proposes the investigation of Role Playing Games (RPG) in the educational context, as a way of facilitating the learning of physics for students. The main assumption for using RPGs is that they can function as a space for teaching based on ill-structured problems. Ill-structured problems are situations where a solution is needed, but the individuals involved do not know the obvious ways or means to get them. They are useful in physics in understanding students' conceptions of scientifically structured concepts as well as working on different meanings for structured problems. An adventure was elaborated in the FATE system and two applications of RPGs in the educational context were made, with students in different teaching situations. It is concluded that role-playing can be useful as a parallel activity to traditional classes and as an incentive for the problematization of physical concepts for students.
\end{abstract}

Keywords: Games and Education. Physics Teaching. RPG. Role Playing Game. 


\section{Apresentação}

Nove pessoas são escolhidas para uma missão arriscada: pousar em um asteroide que cruza o sistema solar, com objetivo de investigar a sua "estranheza". Esses nove astronautas foram selecionados por suas capacidades experiências e conhecimentos variados que ajudariam nessa missão, que é descobrir os mistérios que envolvem esse estranho objeto celeste que apareceu no espaço. Lovelace, como é nomeado o asteroide, possui uma trajetória peculiar, e aparenta ter um formato completamente esférico - uma anomalia para um corpo celeste desse tipo. Essas características indicam que Lovelace na verdade pode ser um objeto produzido por uma inteligência alienígena. É uma obrigação da humanidade fazer um esforço conjunto para descobrir mais sobre Lovelace e os nove astronautas são os nossos representantes.

Esse é o mote principal da história de um jogo de RPG, sigla para Role Playing Game, que foi mestrada por mim para estudantes de cursinho pré-vestibular e do ensino médio da rede pública de São Paulo, que interpretaram os astronautas citados acima. E esta pesquisa investiga, partindo dessa história espacial, como o RPG pode se aliar ao ensino de física para formar uma situação lúdica a fim de trabalhar problemas abertos.

O RPG como tema de pesquisa na área de ensino de física surgiu para mim na discussão sobre o tema da minha pesquisa de mestrado. Eu pensava em escolher algum tema que gostaria de aprender e conhecer mais, com o objetivo de ampliar meus conhecimentos e consequentemente aprimorar minha formação como acadêmico e professor. Inicialmente pensamos sobre o ensino de cosmologia no ensino médio, e depois no ensino para estudantes em privação de liberdade. Mas tive grandes dificuldades com o tema. Grande parte dessa dificuldade era que eu não tinha familiaridade com a linha de pesquisa.

Pensando sobre qual tema de pesquisa escolher, tive uma conversa com meu orientador, em que ele me disse como a pós-graduação era um processo muito difícil e exigente, eu deveria escolher um tema pelo qual fosse apaixonado. Eu adoro jogos. Eletrônicos, de tabuleiro, de cartas... E o RPG é um dos meus favoritos porque ele tem possibilidades quase infinitas de interações, tornando o jogo muito divertido e diverso. A partir daí começamos a pesquisar como usar jogos e o RPG no ensino de física. Desse início até a finalização do mestrado foi um longo 
caminho, e no final chego a conclusão de que o estudo de jogos e educação é um campo de pesquisa muito interessante e possibilita pensar diversas questões sobre o ensino de ciências.

A dissertação está dividida em 8 capítulos. No capítulo 1 está a introdução, apresentando brevemente o que é o RPG e um problema aberto, e como esses dois objetos podem ser usados no ensino. O capítulo 2 contém os objetivos desta pesquisa. O capítulo 3 é destinado à discussão da literatura que aborda diversas questões pertinentes à relação entre jogo e o ensino, além da discussão de problemas abertos dentro do ensino de física. O capítulo 4 descreve a metodologia utilizada. No capítulo 5 encontra-se a descrição do sistema de regras Fate e da aventura preparada para jogar com os estudantes. No capítulo 6 descrevo a aplicação piloto com estudantes do cursinho popular da PUC, que serviu como teste para o jogo principal com os estudantes e as análises dos áudios das sessões das duas aplicações, colocando como recorte a interação dos estudantes no jogo e os problemas de física que apareceram durante as sessões. No capítulo 7 estão as considerações finais do trabalho e as conclusões tiradas da pesquisa, além de apontamentos para futuras aplicações do RPG em contexto educacional. Por fim, as referências bibliográficas utilizadas na pesquisa. 


\section{Introdução}

A presente pesquisa analisa a inserção do Role Playing Game (RPG) no contexto educacional, com o objetivo de facilitar o uso de problemas abertos sobre os conteúdos trabalhados no ensino de física. A premissa principal deste trabalho é de que o RPG pode se tornar uma ferramenta útil para o ensino de física para estudantes do ensino médio, por meio de proporcionar um espaço lúdico para se trabalhar questões científicas.

O principal problema investigado nesta pesquisa é analisar o RPG funcionando como uma atividade que possibilita uma nova forma de trabalhar os conteúdos de física lecionados no Ensino Médio. O ambiente lúdico e a construção de histórias colaborativas, duas das principais características do RPG, podem auxiliar a inserção metodologias investigativas para se trabalhar o conteúdo científico. Neste trabalho, as duas características comentadas acima serviram para se trabalhar problemas abertos de física com estudantes de um cursinho pré-vestibular e da segunda série do Ensino Médio da rede pública de São Paulo.

Mas afinal, o que é o RPG? Role Playing Game, ou Jogo de Interpretação de Papéis, é um jogo de criação de histórias de forma colaborativa, que tem grande proximidade com o teatro. Os instrumentos necessários para o jogo são lápis, papel e dados de formas variadas. No RPG os jogadores interpretam personagens majoritariamente fictícios e o sucesso ou fracasso de suas ações é decidido no rolar dos dados.

O primeiro RPG foi criado em 1973 nos Estados Unidos, por Gary Gygax e Dave Arneson, que realizaram a passagem dos jogos de guerra e estratégia para um mecanismo mais interativo, com ações delimitadas pela imaginação dos participantes, que não controlariam mais um exército, mas apenas um único personagem. O jogo foi intitulado Dungeons \& Dragons, e é considerado o primeiro livro de RPG da história (VASQUES, 2008).

Na maior parte dos casos quem dá início à partida de RPG é o Mestre, também chamado de Narrador ${ }^{l}$, que prepara com antecedência o começo da aventura. Chama-se aventura a sessão, ou o conjunto de sessões de um jogo, que envolve a história dos personagens jogadores e a trama criada inicialmente pelo Narrador.

\footnotetext{
${ }^{1}$ Escolhi chamar de Narrador, porque é assim que o sistema Fate, que eu escolhi para elaborar a aventura, trata. Mais informações no capítulo 4.
} 
É também papel do Narrador definir os seguintes aspectos gerais da aventura: o mundo em que se ambienta, o cenário em que os personagens principais se encontram, além dos possíveis desafios e surpresas que os outros jogadores terão que enfrentar (MARCATTO, 1996; AMARAL, BASTOS, 2011). Os outros jogadores interpretarão os personagens principais dessa aventura, definindo suas ações e falas a partir do que o Narrador vai contando e descrevendo. Os temas das aventuras podem ser baseados em histórias fantásticas, por exemplo inspiradas no clássico Senhor dos Anéis, escrito pelo sul-africano J. R. R. Tolkien, temas de terror e ficção científica, ou mesmo baseados em cenários realistas e cotidianos.

Uma das principais características do RPG é que a história da aventura, apesar de ser esboçada inicialmente pelo Narrador, se constrói de forma colaborativa entre o Narrador e os outros jogadores, que definem o curso da história através de suas ações. A partir dos anos 1990 os RPGs começaram a adquirir uma grande variedade de regras e formatos.

Existem também os RPG eletrônicos, que são jogados em plataformas virtuais, como computadores e videogames e os MMORPG, sigla para Massive multiplayer online role-playing game, ou jogo de interpretação de personagens online para quantidade massiva de múltiplos jogadores. Minha experiência com os RPGs eletrônicos mais famosos, como Dragon Age, Mass Effect e Elder Scrolls, mostra que apesar de possuírem personagens criados pelos participantes, possuem histórias mais fechadas e bem definidas, sem uma colaboração expressiva dos jogadores para a narrativa. Isso acontece por uma impossibilidade material de se criar um software que possibilite um jogo eletrônico com uma história tão aberta quanto a imaginação dos jogadores.

A criação de histórias de forma colaborativa, o que ao meu ver é a principal qualidade do RPG, é constantemente apontado como uma característica que auxilia o processo de ensino e aprendizagem (NASCIMENTO, PIASSI, RAMOS, 2010). Como encontrado na literatura, o RPG se torna uma proposição viável para uma nova abordagem para o ensino de Física, graças a sua característica de criação em grupo:

Propomos a apropriação da máquina narrativa disponibilizada pelo RPG para apresentar ao aluno temas tidos como difíceis sob a roupagem de entretenimento lúdico. Tal é possível por não ser o RPG propriamente um jogo, mas um instrumento de autoria coletiva cuja proximidade ao teatro lhe confere um forte papel socializante: essencialmente cooperativo, não estimula a competitividade e pode contribuir para aumentar a autoestima e motivação dos alunos em sala de aula, permitindo que professor e aluno não desempenhem os papéis costumeiros de detentor do conhecimento e aprendiz, mas de organizador e participante. (NASCIMENTO, PIASSI, RAMOS, 2010). 
De acordo com os autores, o lúdico e o papel socializante são características do RPG que podem ser usadas para facilitar o aprendizado dos alunos, e possibilitar uma reconstrução das relações entre professor e aluno, além dos procedimentos que permeiam o universo da ciência e da física. Reconstruir e imaginar atividades científicas pode motivar os alunos, além de aproximálos de questões científicas pertinentes, que parecem tão distantes das salas de aula.

Neste trabalho utilizamos o RPG e sua característica lúdica e participativa para investigar como os alunos lidam com os problemas abertos que aparecem no jogo. Uma das hipóteses desta pesquisa é que os aspectos principais do RPG, a ludicidade e a criação de histórias colaborativas, ajudem os estudantes a discutir os conceitos físicos. É esperado que os estudantes usem o jogo para formular e debater questões físicas, além de imaginar soluções para problemas encontrados dentro da aventura.

Dentro da aventura foram trabalhados problemas abertos, que diferente dos exercícios de física, não possuem uma solução numérica única e não possui apenas uma forma de solução. É considerado aberto pois pede uma solução para a qual os indivíduos envolvidos não conhecem meios ou caminhos evidentes para obtê-las, além disso os estudantes não conhecem todas as variáveis envolvidas na questão.

Para resolver esse tipo de problema, é necessário levantar e testar hipóteses, tentar obter mais informações e fazer uso de estimativas, aproximações e idealizações (OLIVEIRA; ARAÚJO; VEIT, 2017). Dentro do RPG essa situação de levantar hipóteses e fazer estimativas é uma situação comum, pois os jogadores estão constantemente envolvidos em problemas e conflitos no qual não existe uma solução única.

Esse tipo de problema é uma forma de trabalhar o conhecimento físico, diferente dos exercícios que funcionam como um processo de fixação, levando os estudantes a aplicar equações aprendidas em sala de aula, ou usam estratégias pré-estabelecidas (PÉREZ et al. 1990), e ao meu ver, podem se encaixar melhor num contexto de jogo do que exercícios de física comuns, como os usados no vestibular.

É importante frisar que tanto os problemas abertos quanto os exercícios são importantes para a formação em física. É necessário para aprender física exercitar a habilidade de interpretar os dados fornecidos e conhecer as estratégias mais comuns para resolver exercícios de corrente elétrica ou Leis de Newton por exemplo. Porém existe uma evidente predominância dos exercícios de fixação e aplicação de equações sobre os problemas abertos (PEDUZZI, 1997). 
No ensino de física a resolução de exercícios/problemas tem um papel importante no aprendizado dos estudantes, principalmente como forma de fazer os alunos conhecerem novas formas de pensar o conhecimento apresentado pelos professores, como também outros métodos de avaliação. Majoritariamente as avaliações, tanto no ensino médio quanto na universidade, são feitas por exercícios, verificando se os estudantes aprenderam os mecanismos necessários para resolver tipos específicos de situações físicas. Apesar da verificação destes mecanismos ser importantes, elas não cobrem diversas partes do aprendizado de ciências. Como Daniel Pérez et al. (1990) apresentam em seu artigo:

É certo também que em ocasiões, inclusive comuns, os alunos introduzem ideias errôneas quando formulam hipóteses. Por exemplo, quando se pede qual será a altura máxima que chegará uma pedra lançada para cima, muitos alunos pensam na massa do objeto como uma variável pertinente. Mas isto, antes de ser negativo, constitui talvez a melhor maneira de trazer à luz e tratar tais ideias (que serão negadas pelos resultados obtidos): cada vez que os alunos abordam uma situação problemática na qual intervém uma queda de graves, suas ideias acerca da influência da massa podem reaparecer como hipóteses e serem tratadas; por outro lado, a resolução de dezenas de exercícios habituais sobre este mesmo tema não impede que uma importante porcentagem de alunos de segundo grau e inclusive estudantes universitários continuem considerando como evidente que um corpo com o dobro da massa de outro cairá na metade do tempo gasto pelo primeiro. (PÉREZ et al. 1990).

Uma característica interessante dos problemas abertos é a capacidade de investigar essas concepções errôneas formuladas pelos estudantes, que podem passar despercebidas pelo professor na resolução dos exercícios habituais de lápis e papel. Como citado acima, um estudante pode muito bem resolver exercícios de queda livre de objetos, e ainda acreditar que a massa influencia na velocidade de queda de um objeto. Mas pode-se utilizar problemas abertos em que é possível verificar, na elaboração de hipóteses para encontrar a solução, se o estudante está considerando a massa dos objetos como uma influência da velocidade da queda livre do mesmo;

No artigo acerca das contribuições do psicólogo soviético Sergei L. Rubinstein sobre o pensamento na resolução de problemas, Ruben de Oliveira Nascimento (2017) comenta que o processo de resolução de problemas não acontece de forma mecânica, como acontece com os exercícios tradicionais e tão pouco a solução do problema aparece de forma intuitiva, de maneira não preparada e não condicionada. Para Nascimento, Rubinstein argumenta que existe uma 
correlação entre os elementos de um problema e os envolvidos em sua resolução, que faz com que estes elementos se manifestem com qualidades novas. Ou seja, os elementos iniciais do problema, ao serem incluídos em novas relações propostas pelos estudantes/jogadores envolvidos, aparecem de forma diferente, com diferentes qualidades conceituais.

Essa é uma característica interessante dos problemas abertos: eles possibilitam que os estudantes criem uma relação dialética entre as informações iniciais e a solução do problema, de forma que estas informações sejam rearranjadas, formando novas combinações que caminhem em direção da solução, e por isso permitem novas impressões de conceitos físicos aprendidos em sala de aula. Essas experiências não podem ser alcançadas apenas exercícios matematizados de fixação (RUBINSTEIN, 2017).

Em seu artigo, Oliveira, Araújo e Veit (2017) revisam a literatura de problemas abertos em ensino de física. Eles argumentam que esse tipo de problema favorece a aprendizagem profunda de conceitos físicos, facilitam a transição entre as experiências da vida cotidiana e a compreensão dos conceitos físicos, além de forçarem os estudantes a terem um papel ativo em suas aprendizagens.

A premissa desta dissertação é que o RPG cria um ambiente favorável para aplicar os problemas abertos aos estudantes. O jogo se torna uma atividade onde estudantes podem exercer de forma lúdica um papel ativo na investigação de um problema ficcional, porém contendo contexto e conceitos científicos. Como mencionado por Nascimento, Piassi e Ramos (2010), a mudança do papel do professor para o de narrador confere a possibilidade de organizar o conhecimento dos alunos acerca do problema dado e os estudantes como participantes da construção deste problema e da sua maleabilidade de aplicações dos conceitos da física.

Para essa pesquisa desenvolvi uma aventura usando os sistemas Fate e Fate Acelerado, que foi jogada com alunos e alunas do Cursinho Popular da PUC e da escola estadual Dona Ana Rosa de Araújo, situadas na cidade de São Paulo. A aventura foi usada para investigar como jogar RPG aliado com objetivo de ensinar conteúdos de eletromagnetismo e termodinâmica aos estudantes. O jogo piloto ocorreu com estudantes de um cursinho pré-vestibular, que tem como objetivo proporcionar conhecimentos necessários para provas de ingresso à universidades públicas. Já a aplicação principal ocorreu com estudantes da segunda série do Ensino Médio de uma escola pública situada no bairro do Butantã. Os estudantes de ambas aplicações foram voluntários e seus nomes foram alterados para manter a privacidade dos mesmos. 


\section{Objetivos}

O objetivo desta pesquisa é investigar como o RPG, funcionando como um ambiente para a utilização de problemas abertos, pode se tornar um aliado para se trabalhar conceitos científicos voltados para o ensino médio.

Não tive a intenção de usar o RPG para ensinar um conteúdo específico, como campo elétrico, ou avaliar se os alunos aprenderam esses tópicos, mas analisar como os alunos lidam com problemas científicos que apareceram no decorrer da aventura. A intenção é analisar como os alunos concebem alguns conceitos físicos, como gravidade e movimento, além de observar como resolvem os problemas, inseridos dentro do jogo por mim ou por eles próprios.

Minha pesquisa é pautada em saber se o RPG pode ser jogado de forma educativa e como estudantes interagem com problemas científicos que não tem uma única solução ou uma via única de abordagem. Ao meu ver esse tipo de problema se encaixa melhor com a estrutura de jogo de um RPG que outras abordagens utilizadas no ensino de física, como experimentos ou exercícios clássicos de livros didáticos. 


\section{Referencial Teórico}

A pesquisa investigou como os alunos de um cursinho popular e da segunda série do ensino médio lidam com problemas abertos, que não tem apenas uma forma de resolução ou resposta. Os problemas estão inseridos dentro do RPG. Portanto o foco da pesquisa na literatura são obras que analisam e discutem o uso de jogos na escola, pincipalmente jogos que não fossem eletrônicos e que utilizassem a interpretação como um dos elementos lúdicos.

Parte da literatura utilizada é mais específica e focada no RPG e seus possíveis usos dentro do ensino de ciências. Este capítulo, sobre o referencial teórico está dividido em duas partes: a primeira comenta a pesquisa sobre jogos como o RPG, e seu uso no contexto educacional. A segunda parte é específica sobre os problemas abertos, sua definição e usos dentro do ensino de ciências.

É importante comentar que alguns temas importantes desta área de pesquisa foram deixados de lado na discussão teórica, pois já foram muito bem elaborados em outros trabalhos de pesquisadores do campo. Entre alguns exemplos destes temas estão um debate aprofundado sobre a definição de um jogo, os tipos de jogos (explícitos ou implícitos) que podem ser utilizados no ensino de ciências (Rodrigues, 2013) e a diferenciação entre jogo educativo, didático e pedagógico (Cleophas, Cavalcanti e Soares, 2018).

\subsection{Jogo e ensino}

Talvez o estudo mais famoso sobre o jogo e a cultura seja o livro Homo Ludens: o jogo como elemento da cultura, escrito pelo historiador e linguista holandês Johan Huizinga, publicado originalmente em 1938, com sua tradução publicada no Brasil em 1980. Em sua obra Huizinga defende que o jogar é base importante para a formação da cultura e diversas atividades humanas são marcadas pelo jogo, como a linguagem, a política e os esportes.

Huizinga (1980) define o jogo inicialmente como uma atividade voluntária, e que pode ser substituída a qualquer momento. O que torna o jogo uma necessidade para seus jogadores é o 
prazer gerado pela atividade de jogar. Ele não é imposto por nenhuma necessidade física ou moral. Ligada a liberdade intrínseca do jogar, está a segunda característica do jogo: ele não faz parte da vida corriqueira. Para Huizinga o jogo é uma forma de escape e evasão da vida real, para um lugar de fantasia, uma esfera temporária de atividade com orientação própria. Jogando, as pessoas produzem um intervalo nas leis e costumes cotidianos, podendo agir de forma completamente diferente.

A prática de jogar aparece na grande maioria das culturas e é parte importante da vida das crianças. Os jogos de papéis são oportunidades únicas para a criança desenvolver seu papel no mundo, sua identidade e sua voz (STETSENKO; HO, 2015). Já o psicólogo soviético Daniil Elkonin formulou que os jogos protagonizados, efetuados pelas crianças em idade pré-escolar, são uma etapa importante do aprendizado e inserção na sociedade, é uma forma de apreender e reelaborar as interações de trabalho e socialização do mundo adulto (ELKONIN, 1998).

Stentsenko e Ho (2015) argumentam que o espaço para jogar e brincar é crucial para o aprendizado, não necessariamente de conteúdos, mas habilidades de criatividade e imaginação. Além disso, jogar é uma ação em que as crianças podem se tornar autoras de si mesmas e do mundo. Como é comentado no artigo:

Ao enfatizar as continuidades entre o jogo e todos os esforços criativos humanos e, por extensão, também entre a infância e a totalidade da vida humana ao longo de seu período, nossa sugestão é que não apenas as próprias crianças aprendem muito através de brincadeiras - em um sentido não instrumental de aprendizado, mas sim como descoberta criativa sobre nós mesmos e o mundo. Há muito que podemos aprender através da compreensão do brincar e do que as crianças fazem tão apaixonadamente quando se envolvem nela. (STETSENKO \& HO, 2015, tradução nossa).

As teses centrais de Elkonin sobre o jogo são apresentadas na obra Psicologia do Jogo (Elkonin, 2009), e discutem o desenvolvimento histórico, através de análises antropológicas, como o jogo de papéis surge como um processo importante no desenvolvimento das crianças. Baseandose em sínteses teóricas, estudos históricos, psicológicos e filosóficos, a obra de Elkonin assume a característica de antologia acerca da produção de conhecimento sobre o jogo, relacionando 
estudiosos da antiga URSS e do ocidente, e reúne as principais pesquisas realizadas entre as décadas de 40 e 70 do século XX.

Umas das propostas expostas em Psicologia do Jogo é contrapor a ideia de que o jogo é uma manifestação das fantasias pessoais das crianças ou uma atividade alienante, como defendem diversos autores. O jogo de papéis também não pode ser pensado apenas como uma motivação "natural” biológica que apareceria devido à natureza humana. $\mathrm{O}$ autor comenta:

Em nossa opinião, o singular impacto que a atividade humana e as relações sociais produzem no jogo evidencia que os temas dos jogos não se extraem unicamente da vida das crianças, porquanto possuem um fundo social, e não podem ser um fenômeno biológico. A base do jogo social é devida precisamente a que também o são sua natureza e sua origem, ou seja, a que o jogo nasce das condições da vida da criança em sociedade. As teorias do jogo que o deduzem dos instintos e dos impulsos internos marginalizam, de fato a questão de sua origem histórica. Ao mesmo tempo, a história do surgimento do jogo protagonizado é justamente aquela que pode revelar-nos sua natureza. (ELKONIN, 2009, p. 37).

Apesar da tese de Elkonin ser focada no jogo de interpretação de crianças, ela pode ser aproximada para o RPG, que é também jogo protagonizado pelos próprios participantes. Na minha opinião, o RPG é um jogo que, apesar de ser revestido com um caráter fantástico e que trabalha com a imaginação dos jogadores, tem uma relação muito forte com suas vidas, suas aspirações e visões de mundo.

Através de dados documentais de antropólogos e etnógrafos soviéticos, Elkonin observou que nas sociedades tradicionais as crianças não jogavam o jogo protagonizado devido ao número reduzido de ações e relações sociais e trabalho, e os pais poderiam inserir os seus filhos nas ações cotidianas de trabalho, como a pesca e a caça, a partir da mais tenra idade, sem necessidade de preparação inicial. A medida que as sociedades foram se complexificando e aumentando em quantidade, e as ferramentas de trabalho se tornando cada vez mais elaboradas, foram se desenvolvendo estratégias dos pais para ensinar seus filhos. Entre elas, construir os objetos num tamanho menor, para possibilitar que a criança tenha contato com uma versão simplificada do objeto que usará no futuro em suas ações voltadas ao trabalho.

Jogar é uma forma de acesso ao mundo adulto, e ao mesmo tempo um espaço para o desenvolvimento de habilidades e reconstrução das atividades adultas, e a partir dessa concepção, 
parte para análise das proposições da psicologia ocidental para explicar o jogo das crianças. Elkonin combate a ideia de que o jogo é uma conduta da criança em função do desenvolvimento da imaginação e suas peculiaridades, como a despreocupação e as ilusões derivadas da fantasia, e que o jogo é uma forma de evasão do seu universo limitado. O autor propõe uma observação da situação da criança na sociedade e no sistema de relações da criança com os adultos que a rodeiam.

A ideia da relação entre trabalho e jogo é importante para Elkonin, que toma como base a concepção do filósofo alemão Karl Marx de que o trabalho é anterior à arte e que a humanidade geralmente foca a sua atenção inicialmente em objetos e fenômenos do ponto de vista utilitário e só depois do ponto de vista estético. Partindo da proposição de Marx, o autor argumenta que o jogo e a arte têm uma base genética comum, e que na história da humanidade, o jogo não pode aparecer antes do trabalho ou da arte.

O jogo, segundo o autor, surge quando se separa a parte utilitária da atividade de trabalhar, mas permanece a ação orientada, o qual não é diretamente relacionada com um resultado material. Separada da utilidade e da necessidade de um fim material, o jogo tem desenvolvimentos próprios, mas mantendo sua relação as ações realizadas nas outras esferas sociais. Como diz Elkonin:

Assim chegamos à conclusão de que é o jogo uma atividade em que se reconstroem, sem fins utilitários diretos, as relações sociais. A nossa definição prévia e geral aproxima-se, embora não seja idêntica da de VsevolodskiGuerngross: "Chamamos jogo uma variedade de prática social que consiste em reproduzir em ação, em parte ou na sua totalidade, qualquer fenômeno na vida à margem do seu propósito prático real: a importância do jogo deve-se à sua função de treinamento do homem nas fases iniciais do seu desenvolvimento, assim como o seu papel coletivizador." (ELKONIN, 2009, p. 20).

Ao meu ver, o jogar e brincar comentados por Stentsenko, Ho e Elkonin tem muitas similaridades com o RPG. O jogo que Stentsenko, Ho e Elkonin tratam em suas pesquisas é aquele realizado por crianças em idade pré-escolar, cooperativo e que geralmente lida com a representação dos papéis sociais exercidos pelos adultos, como brincar de mamãe ou professor. Os autores mostram que jogar está intimamente ligado com a forma que as crianças interagem com a sociedade e com os adultos e tem grande influência nas suas formações. Os jogos interpretativos executados pelas crianças têm muitas similaridades com o RPG, por exercitar a atuação em papéis, o ambiente coletivizador e a criação de histórias de forma colaborativa. 
Como o jogo é um espaço de formação e interação com a sociedade, é natural pensar em usá-lo como uma ferramenta educacional. Os PCNs ${ }^{2}{ }^{2}$ oferecerem sugestões e opções metodológicas aos docentes para trabalhar em coerência com os avanços teórico-metodológicos na área educacional, sugerem o uso de jogos como uma opção para o ensino de ciências:

Os jogos e brincadeiras são elementos muito valiosos no processo de apropriação do conhecimento. Permitem o desenvolvimento de competências no âmbito da comunicação, das relações interpessoais, da liderança e do trabalho em equipe, utilizando a relação entre cooperação e competição em um contexto formativo. O jogo oferece o estímulo e o ambiente propícios que favorecem o desenvolvimento espontâneo e criativo dos alunos e permite ao professor ampliar seu conhecimento de técnicas ativas de ensino, desenvolver capacidades pessoais e profissionais para estimular nos alunos a capacidade de comunicação e expressão, mostrando-lhes uma nova maneira, lúdica e prazerosa e participativa, de relacionar-se com o conteúdo escolar, levando a uma maior apropriação dos conhecimentos envolvidos. (BRASIL, 2006).

Além das qualidades explicitadas nos PCNs+, o jogo também possibilita a mudança de postura do estudante em sala de aula. A pesquisadora Bruna Rodrigues, em sua dissertação de mestrado Corrida Vetorial em aulas de Física, argumenta que o aprendizado tradicional de sala de aula é majoritariamente individual, e o caráter coletivo dos jogos promove o compartilhamento de perspectivas diversas. Essa troca de experiências promove o crescimento de todo o grupo de estudantes, por apresentar uma visão multifacetada das situações, além de proporcionar um ambiente de reorganização de concepções equivocadas de como os conceitos são estruturados da Física, como velocidade ou aceleração. Segundo a autora:

Esse compartilhar de conhecimentos e a postura ativa do aluno diante do jogo mudam a posição do aluno para agente do processo ensino-aprendizagem, ao invés de colocá-lo simplesmente como um receptor de conhecimentos (papel assumido pelo aprendiz no modelo tradicional do ensino) (RODRIGUES, 2013).

A autora comenta que esse ambiente de trabalho em grupo proporcionado pelo jogo muda a postura do aluno, que deixa de passiva para uma posição de agência na construção do seu

\footnotetext{
2 Parâmetros Curriculares Nacionais para o Ensino Médio ( $\mathrm{PCN}+$ ), são documentos criados em consonância com a LDB, que propuseram a reorganização curricular em áreas do conhecimento para facilitar o desenvolvimento dos conteúdos, numa perspectiva de interdisciplinaridade e contextualização. O PCN+ influenciou fortemente o campo do ensino de ciências, mas hoje está se tornando obsoleto devido a Base Nacional Comum Curricular (BNCC).
} 
aprendizado. Porém, Rodrigues comenta que esse estudo que acontece em grupo não deve ser totalmente livre. É necessário que seja guiado pelo professor, que será responsável por orientar a visão dos alunos para os aspectos de interesse, e também estar atento ao processo reflexivo dos alunos para identificar possíveis erros na compreensão do conteúdo trabalhado. Como apontado por Nascimento, Piassi e Ramos o RPG permite essa mudança nas posturas tanto de professor e aluno pois professor e aluno não desempenhem os papéis costumeiros de detentor do conhecimento e aprendiz, mas de organizador e participante

Seguindo a tendência de pensar jogos como uma metodologia diferente para o ensino de ciências, e que permitem trabalhar aspectos do aprendizado em grupo e de pró-atividade, surgem os trabalhos sobre RPG e educação. A revisão bibliográfica de Wagner Schmit (2008) é referência muito interessante para esta pesquisa, por estabelecer um estado da arte do campo, fazendo leitura de trabalhos que relacionam RPG e educação e usando a obra de Vygotsky como referencial teórico. Levanto uma definição de RPG do autor, que pode ser encontrada em sua dissertação chamada RPG e Educação: alguns apontamentos teóricos:

Podemos definir o RPG como um que contemple as seguintes características: Ser uma contação de histórias interativa, quantificada, episódica e participatória, com uma quantificação dos atributos, habilidades e características das personagens onde existem regras para a resolução das interações espontâneas dos personagens. Além disso a história é definida pelo resultado das personagens e as personagens do jogo são as protagonistas. (SCHMIT, 2008).

A definição citada toca em pontos centrais da conceituação de RPG que usamos aqui. As características apontadas por Schmit são definições precisas e importantes do que é um RPG, principalmente $\mathrm{o}$ apontamento sobre a contação de história colaborativa e a interações espontâneas entre os jogadores. Se faz importante diferenciar, contudo, sua abordagem daquela que adoto para este trabalho quanto à "quantificação dos atributos, habilidades e características das personagens" como característica do RPG. Essa quantificação é mais fundamental em jogos cuja estrutura se dá pelo caráter estratégico ou em cenas de combate contra adversários construídos pelo narrador. Tendo em vista o ensino de física, existem diversos jogos com alunos que fogem a essa regra, mas também são considerados RPGs pedagógicos. 
Um tipo de jogo que pode ser abordado em sala de aula sem quantização de atributos dos personagens, são os Júris simulados, onde alguns alunos interpretam o papel de jurados, enquanto outros alunos montam grupos defesa e oposição a um determinado ponto de vista. O júri de alunos deve decidir em favor de um dos grupos, baseado nos argumentos apresentados. No trabalho "Uma abordagem CTS das máquinas térmicas na revolução industrial utilizando o RPG como recurso didático", Diego Sabka (2016) desenvolve um jogo de júri simulado para debater questões do desenvolvimento científico e das máquinas térmicas na revolução industrial inglesa. Como ele argumenta:

O jogo simulado pode criar um ambiente em que os alunos vivenciam situações a partir de visões controversas. Quando preocupado com uma formação cidadã, fornecem espaço para o debate de forma que os alunos acabem por repensar seu papel na sociedade. Com isso, eles podem fornecer para a discussão de questões sócio-científicas. (SABKA, 2016).

Apesar de eu utilizar a estrutura do RPG clássico, os objetivos desta pesquisa se aproximam dos contempladas pelo júri simulado. Com o RPG procura-se possibilitar discussões e novas possibilidades de enxergar fenômenos físicos. O RPG, como utilizado na presente pesquisa, tentou ser mais um espaço de debate e criação de histórias em conjunto, do que um jogo de estratégia.

A minha escolha de construir uma aventura vem da literatura. A maioria dos artigos e dissertações sobre jogos e ensino criam cenários e aventuras próprias para jogar com os alunos e decidiu-se fazer o mesmo para esta pesquisa. O campo de estudo do RPG na escola possuí uma literatura diversa, que está crescendo na última década. A aplicação de jogos não é mais novidade, mas um tema que está em fase de aprofundamento e discussão acadêmica (SCHMIT, 2008).

\subsection{Problemas abertos}

Este subcapítulo tem como objetivo discutir problemas abertos no ensino de física e como eles podem ser usados dentro do jogo. A intenção é argumentar que o RPG pode se tornar um espaço propício para a utilização de problemas abertos no contexto escolar. Esta proposta surgiu de duas motivações: o desejo de se inserir jogos na educação, área de pesquisa sedimentada e 
comprovadamente benéfica ao ensino como demonstrado pela literatura citada, e também o desejo de se inserir práticas diversas para se ensinar Física.

Nesta linha argumentativa Laburu, Arruda e Nardi (2003) defendem uma abordagem pluralista do ensino, onde todos os modelos e metodologias tem suas vantagens e desvantagens. E portanto todos os modelos podem servir em algum momento dentro da sala de aula e podem ser substituídos por outro. De acordo com os autores:

O significado geral de pluralismo que pretendemos empregar é mais o de oposição a um princípio único, absoluto e imutável de ordem, do que uma oposição a tudo e a qualquer organização (Regner 1996). Na sua tradução em estratagemas de ensino ele não revela, portanto, ser contra todo e qualquer procedimento metodológico, mas contra a instituição de um conjunto único, frio, restrito, de regras que se pretenda serem universalmente aceitas e principalmente válidas e verdadeiras para qualquer e toda situação de aluno, professor, sala de aula, faixa etária, escola, etnia cultural, lingüística, matéria, conceito, etc. (LABURU, ALMEIDA E NARDI, 2003)

De acordo com os autores, a sala de aula é um ambiente onde os estudantes que lá se relacionam possuem múltiplas identidades culturais. E por esse motivo reagem e são afetados de maneira diversa pelas ações do professor. Assim acabam tendo relações diferentes com o aprendizado.

Ao meu ver, alguns estudantes podem ser atingidos pela didática do professor, se interessarem por física, conseguirem entender os conceitos e outros podem se sentirem perdidos, ou incapazes de aprender devido às estratégias utilizadas pelo professor em sala de aula. O processo de aprendizagem envolve outros fatores além da relação entre professores e alunos, mas me parece uma abordagem interessante o pluralismo metodológico, pois aumentariam as chances de mais alunos conseguirem ver sentido no ensino de física.

Nesta parte do texto minha prática de professor e pesquisador se misturam. Durante grande parte da minha construção como professor de física, atuei em cursinhos pré-vestibulares. Esses cursinhos são focados em treinar os estudantes para terem um desempenho satisfatório nas provas, para que consigam ingressar numa universidade de prestígio acadêmico e educacional. Como forma desse treinamento, os alunos assistem aulas de cunho tradicional, sem aulas experimentais e com um grande enfoque na resolução de exercícios que testam o conhecimento. Esses exercícios, também chamados de "problemas de lápis e papel” por Zylbersztajn (1998) são os encontrados no final de cada capítulo da maioria dos livros didáticos, que exigem a aplicação finita de princípios, 
regras e conceitos de física, sendo usados para simular uma situação-problema restrita. Abaixo um problema de lápis e papel:

Dois carrinhos de brinquedo, de tamanhos desprezíveis, percorrem uma mesma pista retilínea, em sentidos iguais. O carrinho $\mathrm{A}$, que vai à frente, tem velocidade escalar $10 \mathrm{~m} / \mathrm{s}$, e o carrinho B, $12 \mathrm{~m} / \mathrm{s}$. Em determinado instante dispara-se um cronômetro e mede-se a distância entre eles: $22 \mathrm{~m}$. Qual o instante que B alcançará A?(OLIVEIRA, ARAÚJO E VEIT, 2017)

Citado no artigo de Oliveira, Araújo e Veit (2017) como um problema fechado, exercícios como esse são usados para treinar os alunos para o vestibular e em salas de aula da educação básica, tanto para fixar os conteúdos trabalhados quanto para avaliação do aprendizado. Todos os dados necessários para a resolução estão disponíveis no próprio texto e o estudante deve conhecer a definição matemática do movimento uniforme para chegar a única resposta correta para a questão.

Na minha experiência na área de educação tive uma percepção parecida com a apresentada por Zylbersztajn (1998). Os estudantes reclamam e ficam angustiados, porque mesmo estudando a teoria não conseguem resolver os exercícios apresentados no final do capítulo ou na lista criada pelo professor. Ou mesmo quando entendem os exercícios resolvidos em sala de aula, como um exemplo para a ser seguido nas outras questões, os estudantes não conseguem reproduzir esse entendimento quando estão no vestibular ou nas provas avaliativas dos colégios.

Isso gera uma enorme frustração por parte de alunos e professores. Diversos alunos falam que não gostam de física, que são péssimos na disciplina, mas isso muitas vezes tem a ver com a inabilidade de resolver esses problemas fechados, e não com a compreensão dos preceitos científicos da Física ou seus conceitos como aceleração e força peso. Em seu artigo, Zylbersztajn foca a análise na relação desses problemas com o ensino superior, porém acredito que suas observações sejam pertinentes também para o ensino médio:

Estes problemas, conhecidos como do tipo "lápis e papel”, ocupam posição privilegiada no ensino universitário de física, e o fracasso nas situações de avaliação (em geral provas escritas, consistindo principalmente de problemas) é manifestado nos altos índices de reprovação e evasão, principalmente no ciclo básico. A situação, além de frustrante e desmotivadora para os estudantes (como também para os docentes) apresenta ainda reflexos negativos do ponto de vista da eficiência institucional.”(ZYLBERSZTAJN, 1998) 
Esses problemas fechados tem posição privilegiada no ensino de física, e quando usados em excesso, causam os problemas citados acima. Seguindo a linha proposta por Zylbersztajn, Delizoicov, em seu artigo Problemas e Problematizações, comenta que a resolução de problemas tem parte considerável na aprendizagem de Ciências, afirmando que grande parte das aulas são dedicadas a resolver problemas. E teoricamente, o estudante que se dedique a solução dos mesmos, aprenderá os conceitos e os métodos. Isto fez com que os alunos não se interessem pela compreensão da Física, estudando apenas para passar na disciplina.

Antes da análise propriamente dita, Delizoicov faz um breve e interessante comentário sobre a história da pesquisa em ensino de Física. Apesar de ser relativamente recente as teses, artigos e congressos na área - cerca de trinta anos de acordo com o autor, é mais antiga a preocupação de construir uma forma tornar a Física compreensiva para leigos, como estudantes de ensino médio. Diversos cientistas famosos como Albert Einstein, Lev Landal, Mário Schemberg e José Leite Lopes escreveram obras pensando na formação científico-cultural das pessoas. Mas quem destacou explicitamente a importância dos problemas para a compreensão da Física foi o cientista e filósofo francês Gaston Bachelard:

Antes de tudo o mais, é preciso saber formular problemas. E seja o que for que digam, na vida científica, os problemas não se apresentam por si mesmos. É precisamente esse sentido do problema que dá a característica do genuíno espírito científico. Para um espírito científico, todo conhecimento é resposta a uma questão. Se não houve questão, não pode haver conhecimento científico. Nada ocorre por si mesmo. Nada é dado. Tudo é construído (BACHELARD, 1977 apud DELIZOICOV).

Segundo Delizoicov, para saber formular os problemas é preciso conhecer quais são os obstáculos epistemológicos dos estudantes para interpretação do objeto de estudo, para que se possa problematizá-los e enfim superá-los. O obstáculo epistemológico é um conhecimento empírico produzido pelo estudante durante sua interação com a vida cotidiana e que destoa do conhecimento físico. O autor comenta que diversas pesquisas que surgiram depois dos anos 1970 apontam que nossos estudantes já têm diversas idéias pré-concebidas, as chamadas concepções alternativas ao conhecimento construído pela Física. Nas pesquisas, segundo Delizoicov, os alunos empregam de termos comuns à ciência natural, tais como, força, luz, átomo, mas com um significado totalmente diferente daquele conceituado pelas teorias físicas. 
O autor propõe, seguindo as prescrições de Bachelard, que é necessário obter conhecimento sobre essas concepções alternativas, não apenas para saber que ela existe, mas também para incentivar discussões e localizar as limitações dessas concepções, quando comparado com o conhecimento científico. A comparação tem como finalidade de propiciar uma reflexão no educando ao se defrontar o conhecimento científico com o que ele já possui. Além disso, essa comparação objetiva mostrar que a os conceitos físicos podem ser uma alternativa para se pensar a vida que os rodeia.

Pensando na perspectiva de Delizoicov e Laburu, Arruda e Nardi, me pareceu interessante utilizar dentro do jogo um outro tipo de problema para trabalhar os conceitos físicos. Não uma substituição completa, mas proporcionar aos alunos que têm dificuldades com os problemas fechados, uma nova forma de ver a resolução de questões dentro da Física.

Os problemas abertos me pareceram uma alternativa interessante. De acordo com a literatura (Oliveira, Araújo e Veit, 2017), o espaço de discussão e raciocínio criado pelos problemas abertos pode ser usado para superar dificuldades conceituais e epistemológicas dos estudantes em resolver os problemas fechados. Além disso, trabalhar esse tipo de problema com os estudantes abre a possibilidade de se explorar procedimentos que se aproximam do fazer científico, como a análise qualitativa de uma situação, seleção das variáveis importantes para o problema e delimitação da questão abordada.

Em seu artigo de revisão da literatura sobre problemas abertos no ensino de Física, Oliveira, Araújo e Veit analisam 47 artigos sobre o assunto, que possuem as mais diferentes análises e metodologias para abarcar o tema. Apesar das diferenças, os autores apontam que existem alguns parâmetros em consenso sobre a definição de um problema aberto:

a) nem todos os elementos do problema são apresentados; b) existem diferentes caminhos de resolução; c) não admitem apenas uma resposta correta; c) incerteza sobre os conceitos a serem utilizados para resolver o problema; d) necessidade de conhecimento de domínio específico e conhecimento procedimental; e) referemse a um contexto real.(OLIVEIRA, ARAÚJO E VEIT, 2017)

No artigo de Heller apud Oliveira, Araújo e Veit há uma definição de problema aberto que se aproxima bastante de um desafio dentro de uma sessão de RPG. De acordo com os autores, o problema aberto é como uma curta história em que o personagem principal é o aluno. O problema deve incluir uma razão que pareça plausível para os estudantes, e necessite da exposição de suas 
próprias experiências para encontrar a solução. Os objetos do problema podem ser reais ou imaginários e por último, precisam ser suficientemente desafiadores para que um estudante não seja capaz de resolver sozinho, mas não tão desafiador, que impossibilite a solução coletiva.

Para esclarecer, cito dois exemplos de problemas abertos, encontrados no livro didático Física Conceitual, do físico americano Paul Hewitt:

1. Alguém afirma a seu amigo que se algum alienígena de antimatéria tivesse algum dia posto os pés sobre a Terra, o mundo inteiro teria explodido e transformando-se em pura energia radiante. Seu amigo o procura para comprovar ou refutar essa afirmação. O que você lhe diz?

2. Suponha que a população mundial, cerca de $6 \times 10^{9}$ pessoas, seja aproximadamente $1 / 20$ do número de pessoas que já viveram na Terra. Como o número de pessoas que já viveram na Terra se compara com o número de moléculas de ar existentes em uma única respiração.

Ambos os problemas possibilitam diferentes formas de resolução e não apresentam no enunciado todos os dados necessários para resolução. O primeiro tem uma premissa imaginária, e o segundo tem como referência um contexto real. A questão sobre a dificuldade destes problemas é variável e depende de quem está participando da resolução. Porém um detalhe faltando nos dois problemas citados acima é a relevância deles para os estudantes. Heller apud Oliveira, Araújo e Veit garantia a relevância do problema por meio de plausibilidade, ou realidade. A relevância do problema instigaria os alunos a utilizar suas experiências anteriores na procura da solução.

Delizoicov também comenta a importância do processo de significação dos problemas para os estudantes. Segundo o autor, se os problemas forem formulados baseando-se nas concepções prévias dos estudantes acerca dos conceitos físicos:

A escolha e formulação adequada de problemas, que o aluno não se formula, de modo que permitam a introdução de um novo conhecimento (para o aluno), ou seja, os conceitos, modelos, leis e teorias da Física, sem as quais os problemas formulados não podem ser solucionados. Não se restringe, portanto, apenas a apresentação de problemas a serem resolvidos com a conceituação abordada nas aulas, uma vez que está ainda não foi desenvolvida! São, ao contrário, problemas que devem ter o potencial de gerar no aluno a necessidade de apropriação de um conhecimento que ele ainda não tem e que ainda não foi apresentado pelo 
professor. É preciso que o problema formulado tenha uma significação para o estudante, de modo a conscientizá-lo que a sua solução exige um conhecimento que, para ele, é inédito. (DELIZOICOV)

Para Delizoicov, para que o problema seja efetivo em sua tarefa de ensinar os conceitos físico, ele deve ser construído tomando como base as concepções prévias que os estudantes têm sobre esses mesmos conceitos, para assim os problemas terem significado. Como no RPG ocorrem diversos debates entre os jogadores, essas concepções prévias acabam aparecendo, e o jogo assim se torna um espaço para a investigação sobre as concepções alternativas dos alunos.

O RPG pode ser uma forma de construir a relevância dos problemas, e um caminho para que os estudantes se engajem na resolução. A "curta história" dentro do jogo é criada pelos jogadores, que são os personagens principais. Os problemas que vão surgindo no desenrolar da história decorrem diretamente das ações entre os personagens, e entre os personagens e o Narrador. Tanto a criação dos personagens como suas ações dentro da história envolvem diretamente as experiências das pessoas que estão jogando RPG. Suas referências externas sempre aparecem dentro do jogo. Os desafios dentro da sessão sempre envolvem o grupo acabam sendo resolvidos por todos, por meio do consenso. A história é criada de forma colaborativa.

Esta similaridade entre resolução de problemas e o jogo já foi apontado por Moura (1991) em seu trabalho sobre jogos e a construção do conhecimento matemático. Em seu trabalho, Moura argumenta que ensinar a resolver problemas é um objeto de pesquisa frutífero na área de ensino de Matemática, além de um dos principais objetivos do ensino. Na intenção de utilizar os jogos como ferramentas de ensino, Moura busca semelhanças entre os dois tópicos, jogos e problemas. Esta é uma das similaridades apontadas pelo autor:

Na definição de jogo e problema podemos detectar a primeira semelhança, encontrada no sujeito que executa a ação. Para ele, só haverá jogo se nele se instalar a vontade de jogar, se ele entrar na brincadeira. Da mesma forma, o problema só é problema se o indivíduo sentir-se desestruturado (psicologicamente); o problema só é problema se ele é do indivíduo (MOURA, 1991).

Um pressuposto importante para a aplicação de um problema aberto é que o estudante tenha um engajamento em resolvê-lo, e Moura argumenta que o jogo, por também necessitar desse pressuposto para acontecer, se relaciona com a resolução de problemas. O que Moura chama de engajamento, é o que Heller apud Oliveira, Araújo e Veit chama de plausibilidade e tem relação com como Delizoicov conceitua como significação. Plausibilidade está relacionada com 
problemas reais, e o engajamento comentado por Moura tem um significado mais amplo, que pode estar compreendido dentro de um contexto ficcional. Esses autores, ao meu ver, estão conceituando o processo de construção de significado do problema para o aluno, que toca nos pontos levantados por Delizoicov comentados acima.

Minha proposta na pesquisa foi tentar unir os problemas abertos e o RPG por essa característica em comum, a necessidade de empenho por parte dos participantes. O RPG pode criar esse engajamento, de forma que os estudantes se comprometam e acreditem ser necessário resolver um enigma científico que está implícito no jogo. Além disso, o RPG se torna um espaço para os alunos expressarem suas concepções

Outra semelhança entre os jogos e resolução de problemas é sobre a abordagem e compreensão das regras. Moura define que os problemas precisam de uma compreensão inicial da situação e da construção de um plano para a abordar a questão. Em seguida vem a execução desse plano e por último um retrospecto, revisando os passos anteriores e verificando se a resposta obtida faz sentido. O jogo, segundo autor, requer mecanismos parecidos. É necessária uma compreensão inicial do que é o jogo em si e suas regras, para em seguida rascunhar uma estratégia de ação para obter o melhor resultado. Em seguida os jogadores executam suas jogadas, com o plano previamente estabelecido em mente, para no fim avaliar o resultado final, e o que deu certo e errado no decorrer da partida. $\mathrm{O}$ autor faz um comentário interessante sobre o processo de união do jogo e a resolução de problemas:

O professor, ao adotar a estratégia de resolução de problemas ou do jogo, deve fazê-lo no sentido mais amplo do projeto pedagógico: humanizar o homem. E fazer isto é intervir no processo educativo de forma que cada indivíduo possa desenvolver a capacidade de resolver problemas, isto é, que cada homem desenvolva a capacidade de compreender a situação-problema, estando apto a arquitetar um plano, executá-lo e desenvolver a avaliação crítica. Este é o projeto humano. A união entre o jogo e a resolução de problemas está, assim, intimamente vinculada à intencionalidade do professor, que é um dos arquitetos do projeto pedagógico do trabalho coletivo da Escola. Este projeto tem um começo - a cultura primeira - e um fim - a cultura elaborada -, sendo ambos móveis; trata-se do conhecimento em movimento. Aquele conhecimento que é síntese de um processo passa a ser começo de outros, num movimento crescente. (MOURA, 1991).

Então o jogo, no caso o RPG, e a proposta de utilizar problemas abertos fazem parte de um movimento maior da construção de conhecimento. O RPG pode atuar como forma de descobrir algumas das concepções prévias dos alunos para tornar o aprendizado significativo, como comenta 
Delizoicov, e também para fornecer um espaço para se trabalhar problemas abertos. Não devemos substituir os problemas fechados completamente, deixar de utiliza-los por completo. Mas como Laburu, Arruda e Nardi argumentam, buscar um pluralismo metodológico, contribuindo para alternativas ao uso generalizado do estilo dito tradicional de ensinar física, com aulas expositivas e listas de exercício de papel e lápis.

Para que seja possível construir o jogo que foi aplicado com os estudantes, é preciso de uma preparação inicial, e é sobre essa preparação que o próximo capítulo se trata. Com o objetivo de trabalhar os problemas abertos, foi escolhido um sistema de regras dentro os disponíveis no mercado e foi elaborada uma aventura com objetivo de abordar os temas mecânica newtoniana, termodinâmica e eletromagnetismo. 


\section{Metodologia de pesquisa}

Partindo do objetivo da pesquisa, que é investigar o RPG como mediador do ensino de física para alunos do ensino médio, por meio da proposição de problemas abertos dentro do jogo, foi feito um estudo acerca da literatura da área, principalmente sobre o uso do RPG em contexto educacional e também sobre a resolução de problemas e problemas abertos dentro da física. Esse estudo da literatura serviu para delinear o formato da aplicação do jogo com os estudantes e também decidir o foco da análise das interações dos alunos dentro do RPG.

Depois de produzida a aventura, foi realizado um jogo piloto com seis estudantes do cursinho popular da PUC. Os estudantes deste cursinho visavam se preparar para os vestibulares e o ENEM. Eu era professor de física do cursinho e convidei os alunos a participar desse RPG. Os seis estudantes mencionados acima se voluntariaram para participar do jogo. Foram realizadas três sessões de jogo, com cerca de quatro horas de duração cada uma. As sessões foram realizadas no Centro Cultural São Paulo, aos domingos e gravadas em áudio. Nas duas últimas sessões fui acompanhado pelo colega de grupo de pesquisa Maurício Corrêa. Esta primeira aplicação, chamada de jogo piloto daqui pra frente, está descrita com mais detalhes no capítulo 6. É importante constar que os alunos eram maiores de idade e consentiram o uso das gravações em áudio. Além disso, seus nomes foram alterados por questões de privacidade.

Após a conclusão do jogo piloto, analisando os áudios das sessões foi constatada, em conversas com meu orientador, a necessidade de mais uma aplicação do jogo, com outros estudantes. Nessas conversas, juntos com Maurício, analisamos alguns episódios selecionados dentro da aventura, focando em situações onde houve debate por parte dos alunos sobre questões científicas, como a gravidade do asteroide ou instrumentos necessários para medir uma corrente elétrica. Constatamos que durante o jogo surgiram questões interessantes sobre física, no entanto se fez necessária uma segunda aplicação para descobrir mais sobre questões científicas levantadas pelos estudantes e como eles resolviam os problemas propostos por mim dentro do RPG.

Para segunda aplicação foram alteradas algumas etapas da aventura, como por exemplo estender a parte inicial, colocando a questão da escolha da nave pelos estudantes e retirando alguns 
personagens não jogadores. Inicialmente decidiu-se gravar as sessões em vídeo, para captar também as expressões e interpretações dos personagens pelos estudantes.

Essa segunda aplicação foi realizada com nove estudantes da segunda série do ensino médio da Escola Estadual Dona Ana Rosa de Araújo, situada no bairro do Butantã na cidade de São Paulo. Foram seis encontros de duas horas cada um. Os encontros aconteciam de quinta-feira, das $13 \mathrm{~h}$ às $15 \mathrm{~h}$ e eram acompanhadas pelo professor de física dos alunos, o também pesquisador em ensino de física Vitor Fabrício. A segunda sessão foi acompanhada pelo meu orientador e por dois colegas do grupo de pesquisa, Taynara e Lucas. Por problemas técnicos com as câmeras, só a primeira sessão foi gravada em vídeo, as outras sessões foram gravadas em áudio.

Foi elaborado um termo de responsabilidade, assinado pelos pais dos estudantes participantes da segunda aplicação, para permitir o uso das gravações nesta pesquisa e os nomes dos estudantes foram alterados a fim de preservar a privacidade dos mesmos.

\subsection{Coleta de dados}

O RPG é um jogo de conversa e debate. O jogo acontece enquanto os participantes discutem e elaboram a história e as ações dos seus personagens. Tendo em mente essa característica do RPG, assumiu-se que seria essencial para pesquisa gravar as interações entre os jogadores para em seguida analisar episódios de discussão durante as sessões.

No jogo piloto, foram gravados áudios usando o meu celular, e as gravações ficaram satisfatórias. O mais importante era ouvir claramente o que os estudantes falavam durante as sessões, e também era necessário conseguir identificar os estudantes pela voz.

No jogo principal, com os estudantes da segunda série, inicialmente, a coleta de dados aconteceu por áudio e vídeo. Para a gravação em áudio usei novamente o meu celular, pois deu certo na aplicação piloto. Para o vídeo usou-se uma câmera portátil. Porém o cartão de memória da câmera estava com defeito e não estava gravando os vídeos adequadamente. Por isso, a partir da segunda sessão de jogo nesta aplicação principal, optou-se apenas pelas gravações utilizando o celular. 
No jogo principal aconteceu um problema com a coleta de dados, porque alguns áudios ficaram incompletos, devido à memória do celular estar cheia. Então algumas conversas foram perdidas. Além disso, como na aplicação principal o número de estudantes era consideravelmente maior, algumas conversas paralelas não foram captadas pela gravação de áudio, ou ficaram gravadas numa altura baixa, impossibilitando a análise.

Abaixo seguem algumas tabelas sumarizando o jogo piloto e o jogo principal, com o intuito de facilitar a leitura e revisão dos dados.

\begin{tabular}{|l|l|l|l|l|l|l|}
\hline Jogadores & Fernando & Gabriella & Gustavo & Nina & Valéria & Vinícius \\
\hline Personagens & Toby & Latrima & João das & Nika & Safira & Demitrius \\
& Bourdeaux & & Neves & & & \\
\hline
\end{tabular}

Tabela 1: alunos jogadores e seus personagens no jogo piloto.

\begin{tabular}{|l|c|c|c|c|c|c|c|c|}
\hline Jogadores & Alice & Fernanda & Beatriz & Denise & Cristina & Giorgia & Vanessa & Marcelo \\
\hline Personagens & Natasha & $\begin{array}{c}\text { Mayers } \\
\text { Ragna }\end{array}$ & Kira & Danielle & Sofia & Marie & Santos & Thanos \\
& & & & Curie & Dumont & \\
\hline
\end{tabular}

Tabela 2: alunos jogadores e seus personagens no jogo principal. 


\begin{tabular}{|c|c|c|c|}
\hline & SESSÃO 1 & SESSÃO 2 & SESSÃO 3 \\
\hline DURAÇÃO & 4 horas & 4 horas & 4 horas \\
\hline SINOPSE & $\begin{array}{l}\text { Apresentação do RPG, } \\
\text { suas as regras e criação } \\
\text { dos personagens. }\end{array}$ & $\begin{array}{l}\text { Início da aventura. } \\
\text { Jogadores chegam em } \\
\text { Lovelace, entram e } \\
\text { descobrem os } \\
\text { problemas da nave. }\end{array}$ & $\begin{array}{l}\text { Resolução dos conflitos } \\
\text { da nave e a escolha dos } \\
\text { alunos sobre o final da } \\
\text { aventura. }\end{array}$ \\
\hline
\end{tabular}

Tabela 3: breve sinopse e duração das sessões realizadas no jogo piloto.

\begin{tabular}{|c|c|c|c|c|c|c|}
\hline & SESSÃO 1 & SESSÃO 2 & SESSÃO 3 & SESSÃO 4 & SESSÃO 5 & SESSÃO 6 \\
\hline DURAÇÃ̃O & 2 horas & 2 horas & 2 horas & 2 horas & 2 horas & 2 horas \\
\hline SINOPSE & $\begin{array}{l}\text { Explicação } \\
\text { do RPG e } \\
\text { suas regras. } \\
\text { Começo da } \\
\text { criação dos } \\
\text { personagens. }\end{array}$ & $\begin{array}{l}\text { Continuação } \\
\text { da criação de } \\
\text { personagens. } \\
\text { Escolha da } \\
\text { nave do } \\
\text { grupo. }\end{array}$ & $\begin{array}{l}\text { Decolagem } \\
\text { e pouso em } \\
\text { Lovelace. } \\
\text { Chegada a } \\
\text { porta do } \\
\text { asteroide. }\end{array}$ & $\begin{array}{l}\text { Como entrar } \\
\text { na nave? } \\
\text { Problemas } \\
\text { com a } \\
\text { superfície } \\
\text { de } \\
\text { Lovelace. }\end{array}$ & $\begin{array}{l}\text { Pedido de } \\
\text { socorro da } \\
\text { nave. Os } \\
\text { jogadores } \\
\text { recebem um } \\
\text { mapa de } \\
\text { Lovelace. }\end{array}$ & $\begin{array}{l}\text { Resolução } \\
\text { do problema } \\
\text { final } \\
\text { conflito com } \\
\text { inteligência } \\
\text { alienígena. }\end{array}$ \\
\hline
\end{tabular}

Tabela 4: breve sinopse e duração das sessões no jogo principal. 


\section{Elaboração e execução do jogo}

O jogo de RPG começa com a preparação do mestre, construindo um cenário e formulando uma aventura. Foi produzida uma aventura de ficção científica para ser jogada com os estudantes. Não gostaria de usar o RPG como apenas uma ferramenta para transmitir conceitos, mas permitir aos alunos experimentar conceitos científicos, e participar de atividades investigativas, construindo essas atividades coletivamente. Por isso optei por não adicionar muitos elementos escolares dentro do jogo, como tarefas, ou exercícios, tentando deixar a parte educacional o mais diluída possível dentro do jogo.

Minha proposta é permitir, por meio dos jogos de interpretação, que os alunos tenham contatos com situações onde o pensar físico se torne significativo. De forma que o RPG não seja um elemento alienígena para eles, trazido pelo professor e que seja acatado indiscriminadamente, mas algo que faça sentido, que eles também colaborem na criação. Como diz Farchild:

O RPGista lida com essa ambiguidade a todo momento, propondo o RPG como maneira de reformar o ensino, mas, ao mesmo tempo, procurando justamente nas formas consagradas da escola os elementos de sua autenticidade didática. É importante romper com esse movimento, que parece voltar-se sobre si mesmo sem jamais ultrapassar o superficial no debate sobre a escola. Talvez seja o momento de assumir que a escola não apenas transmite, mas produz saberes, e que para escolarizar o RPG é preciso logo que a escola produza o RPG, não apenas o receba. A escola, com efeito, não é um espaço vazio, um canal por onde fluem discursos concebidos alhures, mas uma instituição em pleno funcionamento, dotada de um cotidiano que resiste, como tão bem mostra o exemplo de E13, à intervenção externa. Enquanto o professor não for assumido como parceiro e coautor nesse projeto de escolarização do RPG, é provável que o debate não vá além de uma circularidade ambígua (FARCHILD, 2004).

Pensando em tornar o RPG o mais participativo possível, fui buscar um sistema que integrasse mais o mestre e os jogadores e que tivesse um sistema de regras simples e facilmente modificável. Nessa busca eu encontrei o Fate.

Fate é um sistema para jogar RPG, criado pelos americanos Fred Hicks e Rob Donoghue. A primeira edição foi lançada em 2003, e a quarta e última edição foi lançada em 2013, por meio 
de um financiamento coletivo, organizado no site Kickstarter ${ }^{3}$. Fate é um sistema de regras genérico no sentido de que não está atrelado a nenhum cenário específico, ao contrário de RPGs famosos como Dungeons \& Dragons e Vampiro: a Máscara, que tem ambientações e mitologias pré-definidas.

Fica a cargo dos mestres e jogadores que utilizam o sistema Fate criar as tramas, cenários onde se passam as aventuras, além dos personagens e objetos envolvidos. Como diz um famoso portal brasileiro de discussão sobre RPG, o Fate é o Linux RPG, porque além de ser genérico, funciona no formato de licença aberta, permitindo que mestres e jogadores criem e publiquem suas modificações, cenários, personagens, aspectos e tudo o mais que quiserem relacionado ao sistema, sem infringir nenhuma lei de direitos autorais ${ }^{4}$. Como está escrito no primeiro capítulo do sistema de regras: "Fate não vem com um cenário padrão, mas funciona bem com qualquer ideia que inclua personagens proativos e capazes que vivem aventuras dramáticas”. (HICKS, 2013).

O Fate se utiliza de Aspectos para a formação dos personagens e do mundo onde está situada a aventura. Aspectos podem ser entendidos como conceitos, qualidades ou características. Como encontramos no livro básico:

Aspectos são frases que descrevem algum detalhe significante sobre o personagem. Eles são o que definem porque o personagem é importante (grifo do autor), porque estamos interessados em ver o seu personagem em jogo. Aspectos podem cobrir uma grande variedade de elementos, como personalidade ou traços descritivos, crenças, relacionamentos, problemas ou qualquer outra coisa que nos ajude a identificar o personagem como pessoa e não apenas como um conjunto de atributos (HICKS, 2013).

Os Aspectos podem ser usados em cena pelo jogador e pelo mestre. Eles servem como suporte para história e um mecanismo para facilitar o desenvolvimento da história. No jogo são feitos dois tipos de Aspectos: um que descreve a relação interna entre os personagens do jogo e outro que explicita um defeito do personagem. O primeiro deve ser escolhido pelos jogadores de forma a combinar a história deles dois a dois. Essa relação pode ser de amizade, amorosa ou mesmo de inimizade. O segundo Aspecto fala sobre os defeitos apesar de ser individual de cada personagem, é recomendado que seja escolhido após uma discussão entre os jogadores. Defeito no

\footnotetext{
${ }^{3}$ Kickstarter é o maior site de financiamento coletivo da internet.

${ }^{4}$ Disponível em https://www.rederpg.com.br/2016/03/30/fate-core-ou-sistema-basico-resenha/ acessado em 18 de junho de 2017
} 
RPG é uma característica dos personagens que pode dificultar suas ações dentro do jogo. Eles também são partes constituintes da história e atuam na criação e desenvolvimento da história.

O Fate também propõe uma criação de personagens e de mundos colaborativa, com os jogadores opinando sobre os aspectos que constituem os personagens e o próprio cenário do jogo. Os Aspectos funcionam como um conceito geral que define o personagem e sua atuação nesse mundo, e que está de acordo com o mundo fantástico onde está situada a aventura. Isso significa que as opções de personagens são restritas a formas de atuar dentro do jogo. Por exemplo, o personagem não pode ser um físico teórico numa aventura ambientada no império romano. Ou caso seja, deve se pensar uma justificativa muito boa para isso.

Na primeira aplicação eu usei o sistema básico do Fate, onde existem as Perícias. Elas são quantizações que informam como os personagens podem interagir com o universo ficcional. São as Perícias que influenciam diretamente na rolagem de dados durante o jogo. Os estudantes da primeira aplicação as escolheram dentre uma lista com 18 opções que pode ser encontrada no livro básico. Alguns exemplos de Perícias são: Atirar, Empatia, Vigor, Vontade e Condução. Eles deveriam escolher uma Perícia que seria classificada como "Ótimo" que garante um valor de +4 . Duas serão classificadas como "Bom" e relacionam o valor de +3 as perícias escolhidas. E por último, três Perícias são classificadas como "Razoável", garantindo um valor de +2 . Nina, que criou a professora de dança Nika, escolheu como Ótimo a perícia Vigor. Ou seja, em todos os desafios dentro do jogo que necessitasse que a sua personagem fizesse algum teste relativo à resistência física e fôlego, ela teria já garantido 4 sucessos. No total os jogadores escolhem 6 Perícias dentre as 18 para ter algum bônus, todas as outras, se forem testadas dentro do jogo, não fornecem nenhum bônus nos sucessos, ou seja, são consideradas como +0 .

Já na segunda aplicação eu usei uma modificação do sistema chamada Fate Acelerado ${ }^{5}$. O Fate Acelerado simplifica a mecânica das Perícias, substituindo-as pelo mecanismo Abordagem. Todos os personagens possuem as mesmas seis abordagens: Ágil, Cuidadoso, Esperto, Estiloso, Poderoso e Sorrateiro. Os jogadores devem colocar o valor de +3 apenas para uma Abordagem da sua personagem, que é a forma mais comum que ela resolve os seus conflitos. Duas outras Abordagens terão valor +2 , outros dois terão valor +1 e um item terá valor +0 .

\footnotetext{
${ }^{5}$ Uma versão mais simples do sistema Fate, que pode ser encontrada em https://rpgista.com.br/wpcontent/uploads/2014/03/Fate-Acelerado-DRS-CC-BY-NC-2014-b2.pdf Acessado em 15/07/2019
} 
Citando um exemplo da segunda aplicação, a personagem White Scale é uma hacker habilidosa, possui diversos conhecimentos em informática e conhece diversas formas de burlar sistemas digitais. Assim ela escolheu ter +3 de esperto. Porém a vida de programadora fez com que ela saísse pouco de casa e não ligasse muito para interação social. Isso poderia deixá-la mais desleixada e antissocial, ou seja, pouco estilosa, assim esse valor seria baixo. Esses valores são determinados pelos próprios jogadores, de acordo com como querem construir suas fichas.

A determinação dos Aspectos é importante porque quando uma situação na história necessita ser resolvida pela rolagem de dados, o sucesso ou fracasso da resolução é determinada conforme o número que o personagem tem naquele Aspecto. O jogador vai rolar 4 dados, e vai verificar quantos sucessos foram adquiridos através dos dados. Após isso, ele soma ao número de sucessos o valor que possui na Abordagem que usou. Citando mais uma vez a segunda aplicação, Santos Dumont, personagem de Vanessa, é um engenheiro com um braço biônico que garante uma força descomunal ao portador. Por isso ele possui +3 no Aspecto poderoso. Caso ele chegue em uma rocha e precise quebrá-la com seu braço mecânico, Vanessa vai realizar um teste usando poderoso, e já possui 3 sucessos para realizar esse feito. Quanto maior o número de sucessos, mais bem-sucedida foi ação. Conseguir 5 sucessos é classificado com Excepcional pelo livro de regras, já um resultado negativo é classificado como um resultado Terrível para situação.

O Fate possui um conjunto de dados especial (Dados Fate), usados para as rolagens relativas às jogadas propostas pelos participantes, tanto narrador quanto jogadores. São um tipo especial de dados de seis lados, marcados em dois lados com o símbolo positivo (+), em dois lados com o símbolo negativo (-) e dois de lado neutro, ou em branco. Positivos representam sucessos e negativos os fracassos. Resultados com maior número de sucessos são vantajosos e resultados negativos levam em consequências desastrosas para os jogadores. Apesar de serem dados específicos, eles foram emulados nas aplicações por dados comuns de seis lados, onde 5 e 6 simbolizam o positivo, 3 e 4 o neutro, 1 e 2 o símbolo negativo. Os dados neutros não influenciam na contagem. Se a soma total entre os sucessos e fracassos acabar em 0 , temos um resultado neutro ou Medíocre, como classificado no livro de regras. Isso pode significar que ação que a personagem tentou realizar não deu certo, mas não acarretou prejuízos ou funcionou, mas não teve nenhuma vantagem.

Continuando no exemplo de Vanessa e a pedra no meio do caminho, supondo que ela jogou 4 dados e obteve os resultados 3,1,2,1. Ela conseguiu três dados negativos e um neutro. Somando 
com os 3 sucessos da abordagem Poderoso, a soma total deu zero. Assim na história, poderia acontecer que Vanessa quebrou a pedra, para descobrir logo em seguida que depois da pedra havia um beco sem saída.

A última característica escolhida pelos jogadores são as Façanhas. DE acordo com o livro de regras:

Uma façanha (grifo do autor) é um traço especial do seu personagem que muda a forma como uma perícia funciona. Uma façanha é algo especial, uma forma privilegiada de um personagem usar uma perícia de maneira única, o que é bastante comum em vários cenários - treinamento especial, talentos excepcionais, a marca do destino, alterações genéticas, poderes natos e uma miríade de outras razões podem explicar o porquê de algumas pessoas serem melhores em suas perícias do que outros.(HICKS, 2013).

A Façanha é uma característica especial de uma Perícia ou Abordagem, influindo na rolagem de dados dos personagens. Os jogadores devem escolher duas façanhas, relacionadas às suas Perícias ou Abordagens, de forma que eles adicionam +2 sucessos as jogadas de dados quando usam a Perícia ou Abordagem em um contexto específico.

A aluna Giorgia criou na segunda aplicação a personagem Marie Curie, uma especialista em Geologia. Devido a sua formação nessa área, Curie tinha a façanha relacionada à Abordagem Esperto. Toda vez que a personagem de Giorgia tivesse que fazer algum teste de dados relacionada à análise de solo, minerais ou rochas, ela ganhava +2 sucessos automáticos.

O Fate insere outra dinâmica, diferente dos outros RPGs mais conhecidos, que são os Fate points, que são pontos fornecidos aos jogadores (incluindo o narrador). Eles são usados para que os jogadores tenham uma nova oportunidade de rolar dados que antes tiveram resultados ruins, ou consigam situações vantagens durante a aventura. Já o narrador pode usar os pontos para criar situações desafiadoras para os outros jogadores. Todos começaram com 2 Fate Points, que recarregava a cada sessão, ou seja, se eles gastassem os dois pontos em um dia, eles voltavam a ter dois pontos na próxima sessão. Porém os pontos não acumulavam.

Um Fate Point, quando gasto, possibilita ao jogador poder rolar os dados novamente, caso tenha um resultado insatisfatório na primeira tentativa, ou mesmo realizar um ato incrível. Usando Thanos, criado pelo aluno Marcelo na segunda aplicação, ele poderia voar por um curto período de tempo usando a sua armadura futurista.

Fate é um sistema de RPG que não possui um mecanismo tão complexo em termos de regras para as fichas dos personagens. Outros RPGs, como GURPS ou Dungeons and Dragons 
possuem contas e regras complicadas para determinar os valores das características dos personagens, isso porque estes jogos tem um enfoque diferente para construir a diversão dos jogadores. Enquanto o Dungeons and Dragons tem como o combate e a estratégia como um dos seus fortes, e o GURPS tenta criar um RPG realístico, o Fate tem uma clara preocupação com a criação de histórias de forma colaborativa, e deixando de lado a preocupação com fidedignidade da representação do nosso mundo.

Em comunidades de discussão sobre os RPGs de mesa ${ }^{6}$ e sites de avaliação $^{7}$, constantemente o Fate é considerado um dos melhores sistemas de RPG disponíveis, e uns dos mais acessíveis para jogadores iniciantes. Por ser simples, genérico e maleável, escolhi usar o sistema Fate para a utilizar o RPG no ensino de física. Como quero um RPG não seja demasiado complicado para aprender a jogar e a narrar, porque não tenho muito tempo para a discussão das regras e pretendo utilizar uma aventura que tem um tema específico (problemas científicos), um sistema genérico e com regras e papéis maleáveis, a escolha do Fate me pareceu acertada.

\footnotetext{
${ }^{6}$ https://www.quora.com/What-is-the-best-Generic-RPG-system-available acessado em 03 de julho de 2017

${ }^{7}$ https://www.pastemagazine.com/articles/2015/03/10-tabletop-rpgs-for-beginners.html acessado em 03 de julho de 2017.
} 


\subsection{O Cenário}

O Cenário é a história criada pelo Narrador para que os alunos tenham um começo para desenvolver o jogo. Apesar do RPG ser uma criação de histórias colaborativas, ela deve ter um começo e uma estrutura. É papel do mestre criar esses dois elementos.

Segundo a pesquisadora Sônia Rodrigues, autora do livro Roleplaying Game e a Pedagogia da Imaginação no Brasil, que é o primeiro estudo universitário sobre Roleplaying Game numa universidade brasileira o Mestre ou Narrador é o narrador principal, mas atua também como se fosse um diretor de cena:

O mestre do jogo - sempre autodidata, porque não existem cursos para formar ficcionistas de RPG - é alguém que lê os livros de regras, pesquisa o cenário em que a aventura vai se desenvolver, as personagens, os possíveis antagonistas ou aliados, os caminhos que a narrativa pode seguir no cenário e nas condições propostas. A pesquisa feita pelo mestre tem de ser bem cuidada. Ele precisa ser ágil para calcular, durante o jogo, as possibilidades de desenvolvimento da narrativa, torná-la atraente para os outros jogadores, interagir com eles, responder a suas ações, garantir que a coerência da história seja mantida. (RODRIGUES, 2004)

O trabalho de Sonia analisa três RPG norte-americanos muito famosos: Vampiro: $A$ Máscara, Advanced Dungeons \& Dragons e o GURPS. Na época da pesquisa de Rodrigues eles eram os RPGs mais conhecidos e jogados aqui no Brasil. O sistema Fate é mais recente - foi lançado em português em 2015 - e é considerado um RPG Indie. Por isso é interessante colocar uma citação do livro de regras, porque ele contém uma visão um pouco diferente do que é um Cenário dos outros sistemas citados anteriormente:

Um cenário é uma unidade de tempo de jogo geralmente com duração de três ou quatro sessões e é formado por uma certa quantidade de cenas. Em um cenário (grifo do autor), os $\mathrm{PJ}^{8}$ enfrentarão e tentarão resolver algum tipo de problema (ou problemas) grande, urgente e com um final aberto. O narrador geralmente dá início ao cenário apresentando esse problema aos jogadores, e nas cenas subsequentes os PJs escolhem como lidar com ele, seja procurando informações, adquirindo recursos ou indo direto a fonte do problema. (HICKS, 2015)

\footnotetext{
${ }^{8}$ Personagens Jogadores.
} 
Como forma de cumprir essas diretrizes, tanto de Rodrigues quanto do livro de regras, e ao mesmo tempo trabalhar conceitos de Física com os estudantes, construir uma história de ficção científica apresentou-se a melhor resolução. A referência ficcional para criar o Cenário, personagens e situações que seriam desenvolvidos no jogo foi o livro de ficção científica Encontro com Rama. (CLARKE, 2010), publicado pelo escritor, físico e inventor britânico Arthur Charles Clarke.

Além de ser uma história de ficção que gosto muito, o enredo de Encontro de Rama me inspirou porque fornece uma situação fechada, um enigma a ser resolvido. É um problema a ser explorado pelo leitor junto com os personagens do livro. E esse problema pode ser aplicado aos alunos, que jogarão nos papéis dos investigadores para resolver o enigma do grande objeto misterioso viajando por nosso sistema solar.

Estamos no ano de 2058, e os jogadores interpretam membros de uma iniciativa governamental para investigar um objeto, inicialmente identificado como asteroide, que possui um raio de cerca de $10 \mathrm{~km}$ - o tamanho estimado do asteroide que extinguiu os dinossauros. $\mathrm{O}$ objeto adentra no sistema solar, saindo da órbita de Júpiter e ruma em direção ao Sol. Mas ele não é asteroide comum, pois possui o formato de esfera perfeita, e completamente liso e aparentemente feito de metal.

Detectado pelo observatório mineiro Sonear, e confirmado pela Nasa (National Aeronautics and Space Administration) e a Esa (European Space Agency), e divulgado pela mídia, tal objeto causa comoção mundial e assunto de todas as conversas. Seria essa estrutura exótica uma nave tripulada, um objeto divino, uma arma? Por quem ela pode estar tripulada? Para responder a essas perguntas, um time de pesquisadores, cientistas, peritos e militares é formado pela ONU para ir até o objeto e investigar o que acontece.

Diferente da trama de Encontro com Rama, a nave da aventura se chama Lovelace e não é um ecossistema alienígena, mas um grande computador que viaja pelo espaço. Esse computador contém diversas informações sobre os alienígenas que criaram Lovelace e detalhes sobre a sua tecnologia. Acredito que a metáfora da nave como um computador pode ser uma boa estratégia para explorar conteúdos de ensino de ciência e para trabalhar o teste de hipóteses e investigação. A nave alienígena está com alguns defeitos, e esses problemas contêm informações que se relacionem com conceitos de termodinâmica e eletrodinâmica. 
A nave foi construída por seres pertencem a uma raça alienígena completamente robotizada e informatizada, que vive em um planeta infinitamente distante. Sua nave asteroide na verdade, é um emissário espacial, um grande mecanismo de censo universal, que busca pelas vidas inteligentes do universo. Lovelace é um ser só, constituídos de quatro tripulantes artificiais, que tem como objetivo sintetizar toda a vida inteligente do universo.

Os cientistas alienígenas de todas as áreas, da raça longínqua que criaram Lovelace, têm a intenção de informatizar toda a inteligência do universo. Transformar tudo em todos em informações dentro de computadores. Uniformizar o universo dentro de uma mesma base de dados. Assim por meio das mensagens que enviamos pelo universo, Lovelace detectou a Terra como lar de seres inteligentes, que deveriam ser informatizados e agregados a grande rede de dados.

A missão da nave não é destruir a Terra ou os habitantes, mas tornar todo ser humano também um androide. Todas as pessoas do nosso planeta seriam parte robóticas, com chips implantados e nanomáquinas correndo pelas veias. Transformar o ser humano em indivíduos cibernéticos é uma necessidade para o processo de juntar a humanidade a um grande conselho galáctico. Os jogadores não sabem disso a princípio, mas a ideia é que serão mostrados indícios, durante a aventura, como informações em terminais da nave, inscrições nas paredes, ou "conversando" com os dois habitantes de Lovelace. O enigma final da nave na verdade é uma escolha dos jogadores. A nave está razoavelmente danificada devido a dificuldades durante a viagem. Os jogadores podem escolher consertar a nave, e assim garantir que ela atinja o objetivo final, de integrar a humanidade numa grande rede galáctica, aceitando o fato de mudar toda a sociedade humana e a ideia de humanidade tornando toda parte cibernética, ou desligar e destruir a nave, e assim apagar todo o conhecimento que poderia levar a um desenvolvimento tecnológico e social inimaginável.

A nave é dividida em duas metades, ou quadrantes, e cada um desses quadrantes é controlado por uma inteligência artificial alienígena, as outras duas restantes cuidam de outras funções, descritas abaixo. Cada um dos quadrantes representa um problema a ser resolvido pelos alunos. No centro da nave, que se situa no centro da esfera, existe o core da nave, ou o grande centro de informações, que é o destino final dos jogadores. Para ter acesso ao core da nave, os alunos devem resolver um enigma relacionado com campo elétrico. Existe um campo elétrico que aponta das periferias da nave para o core, então para chegar lá os alunos devem ter suas roupas eletrizadas para conseguir chegar no centro. 
A aventura começa com os alunos, agora no papel de jogadores, decidindo o que seus personagens levarão para aventura. A ida e a volta deles é garantida pela espaçonave que vai leválos até o objeto identificado como asteroide. A comunicação entre os personagens e o centro de comando da missão na Terra tem o atraso de alguns minutos. Eles podem pedir informações para a central, mas levará um tempo até a resposta chegar. Quando eles estiverem no core da nave isso não é possível, porque o core funciona como uma gaiola de Faraday que isola os personagens da central de comando terrestre, então eles têm que lidar com suas próprias decisões.

Até essa parte da aventura, é igual para as duas aplicações. Como o RPG tem como característica principal a construção coletiva da história, a partir deste ponto a aventura mudou bastante entre as aplicações.

Na primeira aplicação a aventura começa com o pouso de Júpiter III (a espaçonave com que os jogadores chegam ao asteroide) numa região em que existem pequenas concavidades na nave, que aparenta ser completamente lisa. Lovelace foi projetada para receber a visita de seres inteligentes capazes de viagens interplanetárias, então por isso possui mecanismos de entrada.

Quando entram na nave, existe um mecanismo de limpeza, que escaneia e retira possíveis agentes nocivos a naves, carregados pelos primeiros visitantes, no caso, os jogadores. Grandes armas ou explosivos, ou mecanismos que possam causar grandes alterações eletromagnéticas não poderão entrar na nave, e serão desabilitados pelo mecanismo de defesa da nave.

Após atravessar o mecanismo de limpeza, os jogadores encontram o programa de defesa de Lovelace. Este programa é uma inteligência artificial chamada Coletivo, que foi o primeiro Personagem do Narrador (PdN) que os estudantes encontraram. Como o nome sugere, ele foi interpretado pelo narrador e o seu objetivo era funcionar como um "guia" dos personagens por Lovelace. As respostas às vezes serão vagas, ou inteligíveis devido às diferenças entre os humanos e a raça que criou Lovelace. Coletivo entra em contato com os jogadores logo quando eles entram, e pede por meios de sinais holográficos que os alunos coloquem algum objeto humano com algo escrito, para que Coletivo possa compreender o idioma dos jogadores. A ideia era que quanto mais material os alunos colocarem a disposição de Coletivo, melhor e mais compreensíveis serão as respostas que ele forneceria aos jogadores.

Depois desse processo, Coletivo aparece como uma imagem holográfica, emulando a aparência de uma das jogadoras, com o objetivo de simbolizar que o ser alienígena simpatiza com os jogadores. Ele explica a arquitetura da nave: em uma das metades está situado a parte de 
armazenamento de dados voláteis, que são os dados de navegação da nave, seu curso, e descrições das condições físicas de Lovelace e o sistema de refrigeração, que está defeituoso e compromete alguns processos, como o sistema de proteção e calibração da rota. Na outra metade estão situados o processador e o armazenamento dos dados permanentes, como as informações sobre a tecnologia e cultura da raça criadora, e qual a missão da nave.

Coletivo comenta também sobre o centro da nave, o core, é onde fica o processamento de dados principal, fazendo a junção das informações fornecidas pelos dois quadrantes da nave, além do sintetizador que colocaria os seres humanos em consonância com a raça criadora da nave e com o resto da galáxia. Esse core fica como se fosse no "céu da nave" e é visível logo que eles entram. Por último, Coletivo pede ajuda para consertar os problemas mecânicos que aparecerão nos quadrantes durante a viagem, e diz que pode fornecer qualquer tipo de ferramenta que os jogadores precisem, desde que eles descrevam o que a ferramenta faz. Por exemplo se eles precisam de fogo, será necessário descrever como é o processo de fazer fogo, que precisa de um combustível e uma faísca.

No primeiro quadrante, está o controle de calor da nave. Quando entrarem na primeira metade, Coletivo deixa de dar explicações, e só fala se for chamado pelos jogadores, pois o setor agora é controlado por K-No (uma referência a Carnot $^{9}$ ), segundo PM do jogo, que tem controle de aquecimento dos seus equipamentos, e das informações desse quadrante. K-No está com defeito, e apenas fala, quando os jogadores entram no quadrante, que logo ela pode colapsar, e fazer com que Lovelace perca o rumo. Além disso, para economizar energia, ela vai desligar sistemas "periféricos”, como portas de entrada e saída nave, e os recursos de sobrevivência, como fornecimento de oxigênio para os jogadores. Então existe uma urgência na resolução do problema, pois os alunos podem nunca mais sair da nave.

Após esse aviso, K-no só repete as frases "quente", "portas e transistor problemáticos" e "perda de potência". Os alunos devem lidar com os problemas das portas e componentes do circuito integrado que superaqueceram durante a viagem da nave, e dilataram de forma que não permitem que os jogadores passem, ou que não permitem que eles consigam ter acesso a informações do segundo quadrante. Eles terão que lidar com os controladores de temperatura da

\footnotetext{
${ }^{9}$ Nicolas Léonard Sadi Carnot foi um físico e engenheiro francês que desenvolveu um modelo teórico sobre as máquinas térmicas, conhecido como o ciclo de Carnot, e apresentou os fundamentos da segunda lei da termodinâmica.
} 
nave, para alterar os materiais, de forma que voltem a conduzir eletricidade corretamente, e que a radiação térmica não atrapalhe a comunicação de dados de Lovelace.

O sistema é refrigerado por água constantemente tratada, e por um grande radiador que possibilita a troca de calor. Para resolver o problema das dilatações e consequentemente do circuito, os jogadores adentram pela tubulação de água e devem desimpedir uma passagem que foi obstruída por pequenas robôs-trabalhadoras que tiveram um problema no software. Os jogadores terão que enfrentar alguns robôs no caminho, tentando encontrar alguma forma de desligá-las ou destruí-las, para enfim obstruir a barreira criada por eles. Por causa dessas barreiras, existem regiões da nave completamente cheias de água muito quente ou muito gelada, e se eles forem passar por essas regiões, eles devem propor formas adequadas de lidar com a situação, como roupas térmicas e respiradores. Quando a água voltar a fluir, o resfriamento voltará a funcionar normalmente, as passagens para o segundo setor serão liberadas, assim como mais informações sobre a nave e sua missão.

Os alunos não sabem inicialmente que o problema é a condução da água, mas um dos indícios é que existe água escorrendo por todo o primeiro quadrante. Sabem também que o setor está a uma temperatura bem alta. Quando os alunos resolverem esse problema, K-no começa a falar normalmente, podendo explicar o que aquela parte da nave faz, quais informações possui, e como pode ajudar os alunos. K-No diz que pode religar os mecanismos de sobrevivência dos alunos, mas tem um problema nas portas, causado pelo segundo quadrante. Então se quiserem ir embora, eles devem ir até lá e descobrir o que acontece. Ela mostrará o caminho para os jogadores para a segunda metade, que agora está acessível.

O segundo quadrante é comandado por Corrente, terceiro personagem do narrador, que fala com os jogadores assim que eles entram no ambiente. Ele explica que ela está perdendo informação. Com o passar do tempo ela está esquecendo as coisas, informações estão sendo perdidas. Ela está sendo desmagnetizada. E se isso acontecer, logo ela pode colapsar, e fazer com que Lovelace perca o rumo. Além disso as portas de entrada e saída deixarão de funcionar, como um recurso para economizar energia. A missão dos estudantes neste quadrante é identificar os setores defeituosos que estão fazendo com que Corrente perca informação.

Corrente explica que seu processo de lembrança tem a ver com uma grande bonina, que ele usa para registrar informação em grandes painéis de uma liga de metal, cujo nome é intraduzível para o português. Essa bobina é um imã que fica mudando de polaridade bilhares de vezes por 
segundo, de forma que alinhe e ionize as moléculas dessa placa de metal, e assim gravando informação. Essas moléculas alinhadas gera um campo magnético, que é captado por outro sensor de Corrente. A variação entre os campos gerados pelas moléculas é transformada em informação novamente, e assim Corrente lembra e relembra suas informações, alinhando moléculas para gravar, e lendo o campo eletromagnético para relembrar.

Porém apareceu recentemente um campo magnético anômalo, gerado em algum canto da nave, que está influenciando na bobina e no sensor de leitura, e as memórias de Corrente agora parecem confusas e atordoadas, e ele comenta que não "consegue se lembrar da combinação que abre as portas, ou de como se faz o acesso ao core". Ela pede aos jogadores que ajudem a encontrar essa anomalia, para que ela possa liberar o acesso até o core da nave, ou para que eles possam voltar para Terra.

Os estudantes devem procuram meios de identificar esse campo magnético e descobrir onde ele está. O campo anômalo é criado por uma construção feita pelos pequenos robôs-operários do primeiro setor, aqueles que ficaram com problema no software. Eles tiveram um problema na forma de funcionamento, e começaram a construir uma terceira inteligência artificial. Quando os alunos descobrirem como achar essa terceira inteligência, seja por um detector de campos magnéticos, como uma bússola por exemplo, ou encontrando algum robô-operário "defeituoso", e seguindo seu curso, eles podem ir ao encontro dela para conversar ou destruí-la.

Essa inteligência e também PdN, que se chama de Ral, foi construída usando ímãs elétricos, bobinas e engrenagens, de forma que o funcionamento de seu circuito está atrapalhando o processo de gravar memórias. Aqui os jogadores devem pensar em um meio de encontrar Ral. Chegando na região onde Ral foi montada, os estudantes são atacados pelos robôs-operários.

Após o combate, os jogadores chegam até onde Ral está localizada. Ela comenta que todas as habitantes da nave são inteligentes, inclusive os robôs-operários, que construíram ela, durante uma "falha" em sua programação, de forma com que ela ajudasse os robôs-operários a serem mais bem tratados dentro de toda a rede da nave. Ral é como uma porta voz dos robôs-operários dentro do sistema da nave, para que suas reivindicações e suas ideias sobre a constituição da nave também possam ser ouvidas.

Ral também pode responder sinceramente qualquer pergunta dos jogadores sobre a nave e seus objetivos e tecnologias disponíveis. Ela é a favor do processo de sintetização dos seres 
inteligentes e de que todos façam parte de uma rede segura, na qual a nave quer inserir todos os seres humanos.

Ela argumenta que diversas conquistas tecnológicas, como teletransporte, comunicação e movimentação acima da velocidade da luz conquistadas por várias culturas, será acessível a todos os seres humanos, e isso só é parte do que será adquirido com a entrada da humanidade neste grande congresso computacional. O que pode ser fornecido também com a entrada de seres humanos dentro da rede alienígena é uma compreensão maior sobre a sua própria ciência e cultura e a construção de conhecimento. Serão novas ferramentas que ajudarão a própria compreensão da humanidade sobre si mesma.

Fica a cargo dos jogadores como lidar com ela. Ral é completamente sintética e está viva. Porém seu funcionamento está influenciando o funcionamento da nave, impedindo os jogadores de continuar a jornada ou mesmo de escapar da nave. Os estudantes têm a escolha de desligar Ral, e assim apagar sua existência, ou procurar uma forma de torna-la mais eficiente, isolando o seu campo magnético. O que os alunos podem propor é, por exemplo, formas de isolar o campo gerado por Ral, ou tornar a suas bobinas e condução de energia mais eficientes, de forma que não atrapalhem o funcionamento da nave.

Quando o problema com Ral estiver resolvido, Corrente falará com os jogadores que ela já tem controle total da nave. Que eles já podem ir embora, investigar melhor os quadrantes, ou ir até o core. Corrente explica que a nave foi carregada eletricamente, agora que está funcionando em plenas condições, e que existe um campo elétrico que aponta em direção ao centro da nave, onde fica o core. E que para chegar até lá, eles devem estar carregados, pois como corpos neutros eles não conseguirão chegar até o centro. Os jogadores então devem bolar um jeito, com a ajuda da materialização de ferramentas que Coletivo dispõe, para se eletrificarem e serem arrastados através campo elétrico, na direção do centro da nave.

O core é o centro da nave, geometricamente e estruturalmente. No core eles encontram a inteligência que controla a nave. Ela não diz seu nome, mas se apresenta como o Representante da civilização distante, e explica que ele está aqui para fazer a proposta de entrada da humanidade na grande comunidade galáctica informatizada. Ela fala aos jogadores que as vantagens disso são inúmeras, que a Terra mudaria de um jeito que os jogadores não poderiam compreender agora, mas que seria possível construir enfim uma sociedade igualitária e infinitamente próspera. Teleporte, comunicação e viagem mais rápidas que a luz, interligação entre todos os sistemas de 
informação, seriam possíveis com equipamentos construídos com o domínio teórico do entrelaçamento quântico. Como nossa mente funciona e como criar uma sociedade onde a palavra é possível a todos e a voz de todos é ouvida e ponderada, o tempo todo. Mago diz que não é o paraíso, mas oferece a chance e as ferramentas para a humanidade sair da infância e se tornar uma comunidade adulta e capaz de construir seus sonhos.

Porém, junto das ferramentas, esse representante diz que todos, os alienígenas e suas inteligências, devem participar da criação das novas estruturas terrestres, e que para isso aconteça, os humanos se tornaram parte sintéticos. A resolução fica por parte dos alunos. Se eles aceitam ou não o acordo proposto, e quais as consequências a escolha desencadeia. É uma escolha final para o destino da humanidade. Eles podem apenas ignorar a nave e ir embora, aceitarem o acordo ou querer enfrentar o Representante.

Durante a aventura todos os personagens do narrador - Coletivo, K-no, Corrente, Ral, Representante e os robôs-operários, são interpretadas pelo narrador. Eles aparecem como hologramas para os alunos, com a exceção das robôs-operárias que são androides, ou seja, elas têm a aparência humana, mas são constituídas de elementos puramente sintéticos, nada orgânico. A aparência delas varia de acordo com o material que os alunos entregaram para Coletivo no começo da aventura.

Esta é a foi a base para a primeira aplicação. Como os estudantes resolveram os três grandes problemas - refrigeração na primeira metade, interferência magnética na segunda metade e a resposta para o Representante, está descrito no próximo capítulo, onde comento com mais detalhes como foi o jogo com os estudantes do cursinho popular.

Houveram diversas mudanças no cenário para a aplicação principal, devido a própria experiência adquirida por mim depois do jogo piloto,e também porque como o intuito agora era mais evidente - verificar como funciona a proposição de problemas abertos por meio do RPG, mudei algumas partes da história que eu acredito que não faziam sentido com esta proposta.

Os PdN foram praticamente todos retirados da história, ficando apenas o Representante, que propõe a escolha final. Tive a impressão durante a primeira aplicação que os alunos às vezes ficavam confusos ou frustrados com as explicações enigmáticas das personagens do narrador.

Os robôs-operários e o combate com eles na área onde Ral foi construída também foi retirado. O conflito é uma parte importante do RPG. Todo sistema de regras reserva uma parte 
específica da sua estrutura para descrever embates entre personagens jogadores e os personagens do narrador, no significado mais amplo do termo, sendo uma discussão de ideias, um flerte ou um combate físico, como uma batalha. Por esse motivo, decidi colocar o combate com os robôsoperários na primeira aplicação. Porém, como aquele combate me pareceu desnecessário para o propósito educativo do jogo ele foi retirado da segunda aplicação.

Foi acrescentado um problema antes deles pousar propriamente em Lovelace: qual módulo eles escolheriam para fazer a aterrissagem. Foi fornecida duas opções, a primeira ofereceria uma maior dificuldade nos testes de pouso, mas facilitaria a partida de Lovelace. Já a segunda opção tem efeitos inversos, ou seja, tem um pouso facilitado, mas dificulta a volta para Terra por parte dos jogadores. A ideia é que essa escolha seja como um problema aberto e incentive o debate sobre as características físicas dos dois módulos, que são descritos com maior detalhe o capítulo sobre a aplicação principal.

Um empecilho novo com relação à superfície externa de Lovelace. Um fluido viscoso composto de uma liga metálica desconhecida na Terra cobre a nave alienígena disfarçada de cometa. A proposta é que essa liga metálica só é possível de ser formada devido a microgravidade de Lovelace, e os alunos poderiam investigar sua composição, que é feito partículas de cobalto e ferro misturado num óleo feito de uma proteína sintética desconhecida.

Foi mantida a porta com indicações luminosas e a gaveta onde os estudantes poderiam colocar os objetos terráqueos para que a inteligência artificial de Lovelace pudesse analisar a linguagem dos jogadores e conseguir criar uma comunicação com eles. A gaveta teve um papel importante na segunda aplicação. Na primeira, ela era simplesmente um recipiente retrátil onde os jogadores poderiam colocar os objetos escolhidos para oferecer a nave. Já na segunda aplicação o recipiente foi reformulado como uma unidade de análise, onde poderiam se observar diversas microagulhas, que eram usadas para determinar o volume e composição dos objetos depositados pelos estudantes.

Porém a porta com indicações luminosas e as agulhas acabaram assustando os estudantes, que ficaram com medo de colocar seus objetos para análise e acabaram decidindo voltar para o módulo de pouso. Essa atitude acabou alterando toda aventura. Os estudantes ficaram muito tempo debatendo o problema de entrar na nave, pensando inclusive em desistir da empreitada de investigar a nave. Por isso acrescentei um mecanismo transmissor, que foi carregado através do fluido que cobre a superfície, com um pedido de ajuda de Lovelace para os jogadores, para que ela 
pudesse cumprir a sua missão inicial, que é oferecer a proposta aos humanos de pertencer a uma grande comunidade galáctica.

Antes de chegar até o representante os jogadores tiveram que resolver um problema de superaquecimento, parecido com o da primeira metade, porém com a resolução desse problema, os jogadores já teriam acesso ao representante da sociedade alienígena. A parte relativa ao problema magnético e gravação de dados na metade comandada por corrente também foi retirada devido ao tempo necessário para realizar a aventura. Como os jogadores gastaram muito tempo no problema de entrar na vae, esse conflito foi retirado do cenário.

\section{As aplicações do jogo}

Inicialmente, como forma de testar o jogo e o sistema, joguei a aventura de RPG de com 6 estudantes do cursinho popular da PUC, como uma atividade paralela às aulas expositivas de física. No final de uma das aulas regulares, apresentei o vídeo que comento abaixo e contei para os estudantes sobre minha pesquisa o sobre RPG e ensino de Física e perguntei se alguns deles gostariam de ser voluntários para o jogo que iria ocorrer aos domingos no Centro Cultural São Paulo. Seis alunos aceitaram participar e foram realizadas 3 sessões de 4 horas, acompanhadas por Maurício, colega do grupo de pesquisa e também mestrando do Programa Interunidades. Irei descrever a primeira aplicação de forma mais breve, porque ela foi um teste para a segunda. Mas na análise faço comparações entre as duas aplicações.

O cursinho popular da PUC é um cursinho popular pré-vestibular criado em 1997 por alunos dos cursos de relações internacionais e ciências sociais da Pontifícia Universidade Católica de São Paulo (PUC-SP). Voltado aos estudantes e concluintes do ensino médio em escolas públicas, as aulas acontecem aos sábados das $8 \mathrm{~h}$ até às $17 \mathrm{~h}$. Os alunos têm entre 16 e 18 anos em sua maioria, e buscam o cursinho com objetivo de prestar o Enem e ingressarem em uma universidade pública.

O cursinho é gerido pelos professores, que determinam os conteúdos abordados e as estruturas gerais do cursinho, como os dias de aula, férias e os trabalhos de campo, para os alunos visitarem pontos importantes da cidade de São Paulo, como o centro ou o Pico do Jaraguá. Optei pela aplicação no cursinho da PUC porque já dava aulas lá há algum tempo, e já conheço os alunos 
desse ano, e acredito que eles teriam confiança em mim para participar de um jogo que eles não conhecem. Dei aula de física no cursinho da PUC nos anos de 2016 a 2017.

Inicialmente apresentarei um vídeo ficcional, no final do primeiro dia de aula depois das férias (05 de agosto de 2017), em que uma suposta oficial de um alto escalão governamental convoca os alunos para a missão, que é investigar o asteroide Lovelace. $\mathrm{O}$ vídeo é uma produção própria para pesquisa, criado com ajuda de amigos ${ }^{10}$. Minha ideia era criar uma convocatória fantástica" para o jogo, como forma de deixar os alunos curiosos e empolgados para participar do jogo. Em seguida expliquei que o vídeo faz parte de um jogo, chamado RPG, e iria jogar junto com eles como uma atividade extra-classe. Por fim, perguntei se alguns alunos gostariam de se voluntariar para jogar.

Os encontros com os alunos acontecerão fora do horário de aula e tiveram aproximadamente 4 horas. Na primeira seção conversei com os alunos sobre RPG e o uso de RPG no ensino de ciências, expliquei como se joga RPG e como funcionam as regras gerais do Fate e pedi para eles construírem um personagem juntos, seguindo os modelos do sistema. Abaixo uma breve descrição dos personagens. Os nomes dos alunos foram modificados.

\section{Fernando}

Criou o personagem Toby Bourdeaux, um grande cientista da computação e hacker.

\section{Gabriella}

Criou Latrima, uma astrônoma de 38 anos com PHD em física quântica.

\section{Gustavo}

Teve como personagem João das Neves, professor de educação física e expert em Parkour

\section{Nina}

Criou a personagem Nika, professora de dança.

\footnotetext{
${ }^{10} \mathrm{O}$ vídeo pode ser visto através do link https://www.youtube.com/watch?v=4Wk4XBxgslA\&feature=youtu.be acessado em 15/07/2019
} 


\section{Valéria}

Jogou como Safira, uma advogada especializada em dinâmica e gerenciamento de grupos.

\section{Vinícius}

Jogou como Demitrius, um agente da CIA que realiza missões impossíveis por todo o mundo.

Os primeiros Aspectos, que relaciona as histórias dos personagens, foram escolhidos pelos estudantes da seguinte forma: Latrima e Safira se conheceram em um Uber compartilhado, onde elas começaram a construir a amizade, que se solidificou quando Latrima e Safira foram à uma aula de dança ministrada por Nika. Toby conheceu Demetrius quando o agente da CIA tentou matar o hacker, após descobrir que Toby estava tentando invadir sua conta bancária. O caso foi ao tribunal, e o lado de Demetrius foi defendido por Safira. João das Neves e Nika são amigos de trabalho, pois são funcionários da mesma academia, onde João ensinava Crossfit e Nika dava aulas de dança.

Já os Aspectos secundários, onde os jogadores classificam os defeitos dos personagens são: João tem medo de altura e sente vertigens olhando para baixo quando está em grandes alturas. Safira é teimosa e gosta de discutir. Latrima é maquiavélica e segue a inspiração de que os "fins justificam os meios". Toby gosta de fazer as coisas rápido, então geralmente seus softwares sempre apresentam alguns pequenos problemas ou bugs. Nika é muito medrosa e Demetrius é tão focado que deixa as pessoas em segundo lugar quando está cumprindo uma missão.

No segundo encontro comecei a narrar a aventura, usando os personagens que eles criaram no primeiro encontro e como base da história, o cenário descrito no capítulo anterior. Os alunos resolveram os problemas de forma inesperada. Os jogadores apresentaram preocupações com a velocidade de rotação e com a gravidade do cometa, e detectaram rapidamente que se tratava de uma nave assim que pousaram e viram as indicações pelo chão.

Os objetos oferecidos na gaveta para Coletivo foram os livros de astrofísica e direito constitucional que levavam na bagagem, um mecanismo comunicador, parecido com um walkie talkie e uma câmera de vídeo. esses objetos ao meu ver demonstram a intencionalidade de querer estabelecer uma comunicação com os tripulantes de Lovelace.

Depois de entrar, eles se separam em dois grupos para resolver os problemas das duas metades simultaneamente. $O$ primeiro grupo notou a água escorrendo pelo setor e foi atrás de onde 
estava a barreira que impedia a água de fluir e fazer a troca de calor. Como a barreira estava numa parte de água muito quente, eles pediram uma roupa térmica para Coletivo. Nesse momento teve uma discussão de como seria a roupa de proteção. Eles queriam se cobrir por completo como forma de se proteger totalmente, e Coletivo fez uma roupa sem nenhum mecanismo ou abertura para a visão do ambiente. Isso fez com que eles reformulassem o pedido, para que ficasse parecido com uma roupa de mergulho.

Para resolver o problema magnético da memória da nave, um grupo composto por Demitrius e João das Neves usou uma bússola para começar a busca por Ral. Chegando lá, após o combate com os robôs-operários eles conversaram sobre as intenções da Ral, e na dúvida sobre o que fazer resolveram carregá-la até a presença de Corrente para ele decidir o que fazer. O campo magnético gerado pelo funcionamento de Ral afeta ainda mais Corrente devido à proximidade. Demitrius sugere a criação de uma proteção magnética para "agulha" (a forma como ele se referia a Corrente). João das Neves é contra, porque ele está irritado com o ataque dos robôs-operários, achando que ele aconteceu por um comando de Ral.

As meninas são veementemente contra desligar Ral, mas elas não estão presentes para participar da discussão dentro do jogo, configurando um meta-jogo entre os jogadores. Meta-jogo acontece quando os jogadores discutem estratégias ou ações como jogadores observando o jogo acontecendo,e não como partes do mesmo. Por exemplo, Gabriella pede efusivamente para Gustavo não desligar Ral, mesmo a personagem dela, Latrima, não estando no mesmo ambiente que João das Neves. Esse comportamento é controverso em mesas de RPG, mas eu permito que os estudantes continuem porque eles estavam envolvidos na resolução deste problema.

No final eles escolhem manipular Corrente, usando a perícia de Comunicação e a rolagem de dados, para que ele abra a passagem até o representante, para que ele tome conhecimento de Ral, e decida o que fazer. Permito esse comportamento também porque eles pareciam não ver outra alternativa. Porém após as duas aplicações percebi que esse comportamento era recorrente.

Os estudantes geralmente conseguem identificar as variáveis importantes do problema e compreender o que está acontecendo em conceitos físicos. Eles identificaram que o primeiro quadrante tinha um problema de aquecimento e que era necessária alguma atitude para equilibrar as temperaturas. Também souberam que o campo magnético tem relações com imãs, e que os campos magnéticos podem se influenciar. Mas para propor uma resolução, geralmente eles 
preferem explorar os mecanismos do jogo, como a utilização das perícias, ou mesmo votação, como ocorreu na segunda aplicação.

Esse é um cuidado importante para se tomar em possíveis próximas aplicações do RPG em contexto escolar. Tentar justificar o máximo possível o uso dos dados, ou quem sabe pensar em um sistema que não use absolutamente esse recurso, para que todos os conflitos acabem resolvidos por discussões e proposições dos jogadores.

O objetivo não era ensinar algum conceito específico de física, mas observar como eles apareciam durante as discussões; se os estudantes usavam esses conceitos que já conheciam para tentar resolver os enigmas presentes dentro do jogo. Porém para determinar quais as variáveis do problema, os estudantes frequentemente pensavam em questões físicas.

Uma das primeiras questões relativa a conceitos de física apareceu durante o pouso da nave dos jogadores em Lovelace:

. Vinicius: "Nós tem sapatos para fixar no chão? Porque tá girando né, e gravidade a gente nem sabe se tem!"

Gabriella: "Mas prô, se a velocidade (de giro) é constante, não parece que está girando né?"

Narrador: "Sim, como ele é muito grande vocês não percebem que ele está girando."

Esse problema proposto por Vinicius no excerto 1 foi surpreendente, não estava esperando que eles questionariam esse aspecto da aventura. Não esperava que a questão de gravidade ou da sensação se o cometa está girando ou não é perceptível. A resposta de Gabriella também é interessante: ela argumenta que se não tem uma aceleração escalar no movimento de Lovelace, eles não terão a sensação de movimento do suposto cometa. Ao meu ver essa interação acaba exemplificando outras diversas situações que acontecem nas duas aplicações. Os estudantes utilizam os conceitos da física para pensar como o problema funciona, mas não usam isso para resolver efetivamente o problema.

Outro exemplo de discussão com conceitos de física que apareceu durante o jogo:

Mestre: Vocês tem que descarregar para poder destrancar (a fechadura).

Vinícius: "mas só a bateria e os fios são suficientes?"

Fernando: "mas o problema é como tirar" 
Mestre: "sim vocês tem que saber onde conectar. Tem que saber por onde está passando a corrente de elétrons."

Gabriella: "Mas não precisa de um equipamento específico?"

Narrador: "Sim, que vocês não levaram"

Mais uma vez os estudantes usaram conceitos e tentaram relacionar o problema de descarregar o sistema de fechadura de uma porta, com os conhecimentos de física que possuíam. Ambas as situações, da movimentação deles pelo cometa e do destravamento dessa fechadura acabaram sendo resolvidos por lances de dados.

Na última sessão terminamos a aventura, com os alunos escolhendo se aliar aos alienígenas. No final pedi para eles desenharem como eles tinham imaginado as cenas que aconteceram durante o jogo, assim como os ambientes onde seus personagens passaram. Conversamos um pouco sobre a experiência do jogo, e os alunos majoritariamente perguntaram sobre o que teria acontecido se eles tivessem tomado atitudes diferentes. Encerramos a sessão com meus agradecimentos a participação deles.

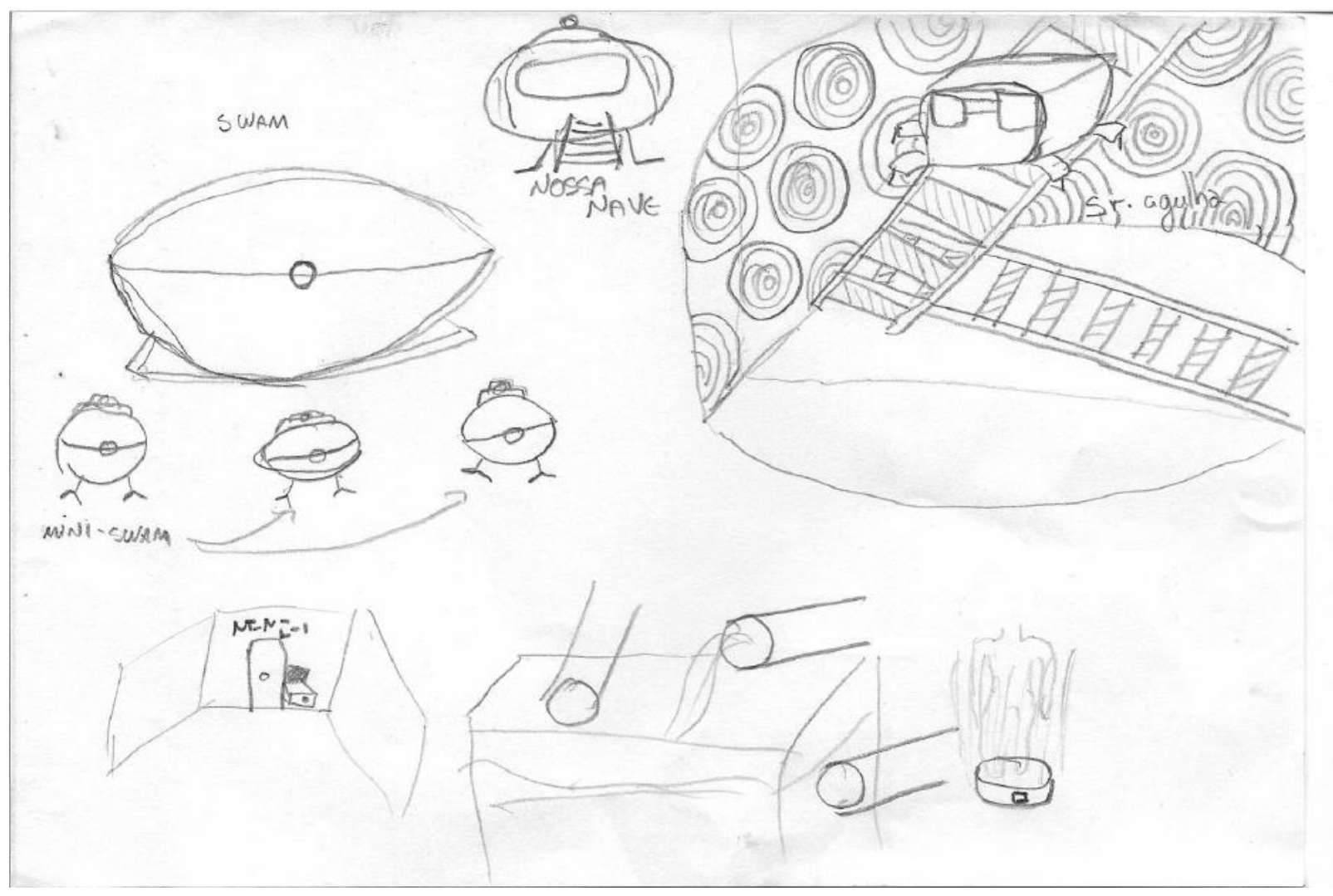

Figura 1: Desenho feito pela estudante Gabriella sobre a aventura 


\section{Ficha de Criação de Personagem}

IDEIA DE PERSONAGEM

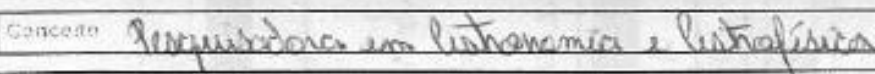

Dificuladado

Wamio Satima

\section{AS TRES FASES}

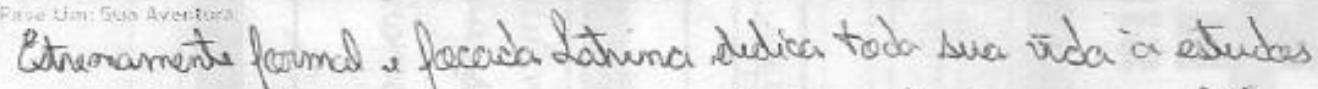
e pesquiises dabre do universo e seu antendimento, tom como ričqui and quande inspinaceor afinal "as fans fuitificam as neios".

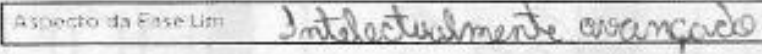

Conhere Safira sna USP, que fulgau o caso de Tdai e Pemitrieis no forum de Sco laulo Juntas, dividirem uin quiosto em uma referblica

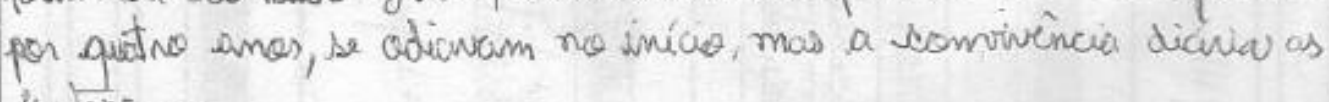
Sunvivam.

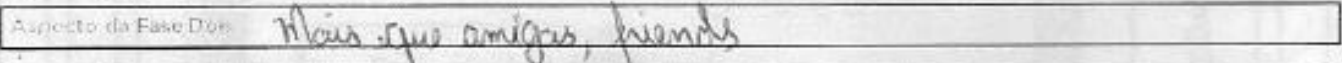

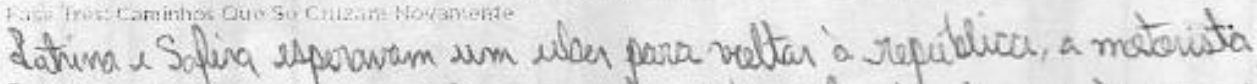

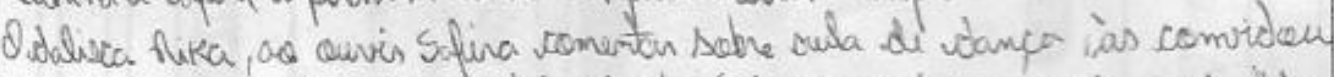
para ter uma cula expevimentil gatuita (ela gra frefessera de domea), datri-

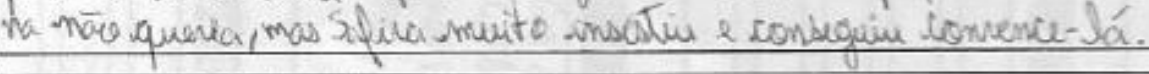

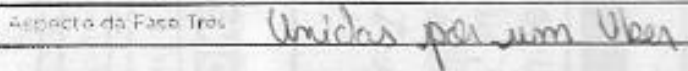

\section{PERICIAS}

- Uma perícia em nivel Ótimo (+4)

- Duas perícias em nivel Bom (+3)

- Trés pericias em nivel Razaável (+2)

- Quatro pericias em nível Regular (+1)

\section{FACANHAS E RECARGA}

- Très Façanhas - Recarga 3

- Quatro Facanhas - Recarga 2

- Cinco Façanhas - Recarga 1

Figura 2: ficha da personagem Latrima, parte da história/aspectos. 


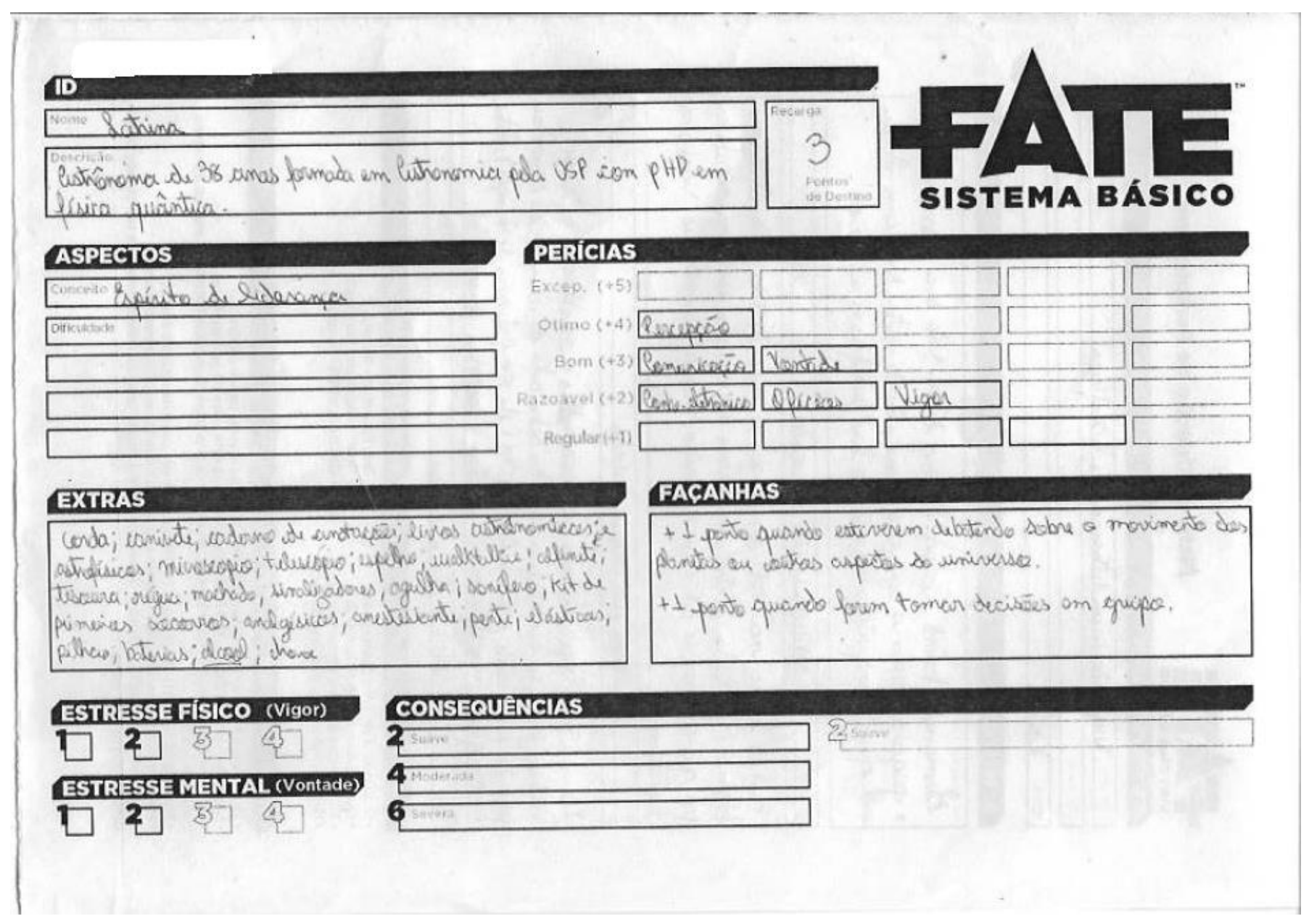

Figura 3: ficha da personagem Latrima, parte das perícias, façanhas e equipamentos.

O passo seguinte era ensinar os alunos a mestrar para os seus colegas de classe no cursinho. Eu atuaria só como um monitor dos seis grupos que seriam formados, com cada um desses estudantes que participaram desta primeira aplicação mestrando para outros colegas de turma. $\mathrm{O}$ planejamento era de a maioria da sala jogasse, ou pelo menos quem quisesse. Mas não pude seguir esse planejamento. A última sessão aconteceu em 08/10/2017. Os alunos já estavam na reta final para o vestibular, então achei melhor abandonar esta proposta de trabalho.

Assim foi pensada uma segunda aplicação para ser feita com alunos do ensino médio. Nesta segunda proposta não tinha como objetivo formar os estudantes para mestrar para seus colegas, mas investigar como eles resolviam os problemas de caráter científico que eram colocados durante a aventura. 


\subsection{Descrição e análise dos áudios da segunda aplicação}

A segunda aplicação ocorreu com 9 estudantes da segunda série do ensino médio da escola pública Dona Rosa de Araújo, situada na cidade de São Paulo no bairro do Butantã. Primeiramente fiz contato com o professor Vitor Fabrício, que leciona física para os estudantes e fiz o convite aos estudantes durante as suas aulas. Vitor acompanhou as seis sessões, como uma exigência da escola para a aplicação do jogo. As sessões aconteciam às quintas-feiras, com duração aproximada de duas horas, entre as $13 \mathrm{~h}$ e às $15 \mathrm{~h}$.

Na primeira sessão, realizada no dia 10/05/2018, constava com 9 estudantes presentes, e nosso objetivo neste encontro era apresentar o RPG, suas regras e o processo deles construírem seus personagens. Também nesta primeira sessão, os estudantes se apresentaram, contaram seus passatempos e comentaram as disciplinas da escola que tinham mais interesse.

As regras utilizadas foram do sistema FATE como comentado no capítulo 5 e os estudantes foram orientados a fazer os personagens seguindo a minha história previamente contada: eles seriam astronautas numa missão até um cometa com comportamento anômalo, que estava nas cercanias da Terra.

Narrador: "Um cenário futurista. Daqui uns 20 ou 30 anos. Muito parecido com hoje, mas com algumas tecnologias que não existem hoje. O personagem precisa ser especial em algumas coisas. Uma missão secreta. A NASA detectou um objeto no sistema solar que não é possível identificar o que é. Tem características de cometa mas não parece perfeitamente, por que ele é esférico. Um bilionário e investidor decide mandar pessoas para lá sem que as agências governamentais saibam disso. Vocês fazem parte dessa missão."

A instrução é que eles fizessem personagens pensando num futuro relativamente distante (entre 30 e 40 anos no futuro) e deveriam ter características especiais para serem convocados para essa missão arriscada. Como forma de exemplificar a criação de um personagem, enquanto eles construíam suas personas ficcionais, eu também criava como o bilionário investidor da história, que foi uma versão fantasiosa e futurística do investidor e empresário sul-africano Elon Musk. Usei Musk como personagem para dar um caráter mais realista à história e também relacionar com as pesquisas espaciais a qual Musk atua no presente. 
Abaixo uma descrição dos estudantes, feitas por eles próprios durante a rodada de apresentações na primeira sessão e seus personagens. Os nomes reais dos alunos foram modificados:

\section{Alice}

15 anos, $2^{\circ} \mathrm{D}$. Gosta de humanas na escola, ler e assistir filmes de super-heróis. Quer ser médica (obstetrícia). Nunca jogou RPG. Criou a personagem Natasha, uma perita criminal.

\section{Fernanda}

15 anos, $2^{\circ}$ E. Gosta de física na escola, de dormir, pensar em dormir e de estudar religião. Não gosta de pessoas. Já jogou RPG. Criou a personagem Mayers Ragna, psicóloga e uma das pilotas da missão.

\section{Beatriz}

17 anos, $2^{\circ} \mathrm{A}$. Gosta de Muay Thay e trabalha como "faz tudo" em uma oficina de motos. Quer trabalhar com medicina e estética. Se declarou como uma líder nata. Nunca jogou RPG. Criou a personagem Kira, uma médica canibal.

\section{Denise}

16 anos, $2^{\circ} \mathrm{D}$. Gosta de exatas e humanas na escola. Gosta também de dormir, comer chocolate, tirar fotos e ler. Odeia açaí. Nunca jogou RPG. Criou a personagem Danielle, uma astrofísica.

\section{Cristina}

16 anos, $2^{\circ} \mathrm{D}$. Gosta de exatas e odeia português/artes. Passa o tempo fazendo artesanato. Quer ser médica (cirurgia geral) e gosta de açaí e café. Nunca jogou RPG. Criou a personagem Sofia, uma médica. 


\section{Giorgia}

16 anos, $2^{\circ} \mathrm{D}$. Gosta de exatas e detesta português. Quer ser médica (pediatra). Já jogou RPG. Criou a personagem Marie Curie, cientista especialista em geologia e matemática. Tem como habilidades fazer grandes contas de cabeça e reconhecer minerais e rochas com facilidade.

\section{Vanessa}

16 anos, $2^{\circ} \mathrm{D}$. Não gosta de exatas na escola, gosta dos assuntos sobre o corpo humano e de dançar. Nunca jogou RPG. Criou o personagem Santos Dumont, um mecânico com uma prótese robótica no braço que funciona por meio de uma bateria.

\section{Marcelo}

16 anos, $2^{\circ} \mathrm{D}$. Gosta de física na escola e de jogar League of Legends e de dormir. Já jogou RPG. Criou o personagem Thanos, um engenheiro mecânico e mecatrônico que também vende armas. Thanos possui um jetpack que funciona de forma parecida com o do personagem dos quadrinhos Iron Man.

\section{Elena}

16 anos, $2^{\circ} \mathrm{C}$. Gosta de física e não gosta de educação física na escola. Como passatempo joga League of Legends, lê e estuda informática. Deixou como declaração a frase "Não há caminho para paz, a paz é o caminho”. Criou a personagem White Scale, especialista em tecnologia e programação.

Alguns trabalhos em RPG, como de Sabka, não possuem criação de personagem, ou possuem personagens já prontos. Eu resolvi manter a parte em que os estudantes fazem seus personagens porque ao meu ver a criação destes é um exemplo de um problema aberto proposto pelo mestre para os jogadores, tomando como base a definição dada pela revisão da literatura apresentada acima. Eles são apresentados às regras e aos procedimentos para construir seus personagens, mas existem incertezas quanto aos elementos que compõem o problema (criar um personagem que seja condizente com o contexto) e também como resolvê-lo. A criação ainda exige dos estudantes julgamentos sobre o problema,_expressando concepções e crenças pessoais. 
Os estudantes acreditavam que seus personagens deveriam ser muito inteligentes para terem sidos convocados para essa missão e a representação desta inteligência e qualificação era o número de cursos superiores. Algumas alunas (Cristina e Elena) disputam quais personagens tem mais faculdades. Eu intervenho em um momento da criação dos personagens, porque uma das alunas (Giorgia) tem ao meu ver um número de diplomas que me parece incompatível com a sua idade. Mas o mecanismo operando por trás desta concepção e chama atenção, e acredito ser um interessante recorte de análise: a criação de personagem é um teste feito pelos estudantes de como funciona este mundo ficcional.

Em um momento, Vanessa, que criou o personagem Santos Dumont pergunta se o personagem dela pode ser um meio dragão. Nos RPGs clássicos como o Dungeons \& Dragons, é comum os personagens serem meio elfos, ser gerido de um relacionamento entre um(a) humano(a) e um(a) elfo(a) ou meio orcs, que são frutos da relação entre humanos e orcs. Essa terminologia "meio" denota uma miscigenação entre as raças do mundo fantástico. Comentei inicialmente sobre o cenário da aventura ser alguns anos mais velho que o nosso mundo atual, então existiriam tecnologias ainda inacessíveis para nós. Porém ser meio dragão não se encaixa no cenário, pois não existem dragões no nosso mundo, muito menos meio dragões, e provavelmente não existiram pelos próximos anos. Ao meu ver Vitória estava testando, na criação do seu personagem, o quão fantástico era o mundo-cenário onde aconteceria a aventura.

Giorgia construiu uma personagem chamada Marie Curie, que era uma geóloga e matemática, e assim "fazia contas de cabeça muito rápido". Santos Dumont e Marie Curie, devido aos seus nomes, aparentam ser os dois personagens que mais diretamente se relacionam com o contexto científico do nosso mundo.

O estudante Marcelo criou o personagem chamado Thanos, o primeiro em referência ao personagem dos quadrinhos e do cinema, criado pelo quadrinista Jim Starlin. Thanos, no nosso jogo, é um engenheiro que construiu para si um dispositivo eletrônico parecido com a armadura do personagem Homem de Ferro. Kyra, personagem criada por Beatriz, também tem esse nome em homenagem à Kira Yukimura, personagem fictícia da série de televisão Teen Wolf.

Apesar dos nomes fantásticos, vetei personagens com conotações mágicas ou sobrenaturais, e assim os estudantes adaptaram seus personagens ao mundo ficcional que eu tinha proposto inicialmente. Então os personagens acabaram bem diferentes de seus homônimos da cultura pop, assim como Dumont e Curie ficaram diferentes do inventor brasileiro e da famosa 
cientista polonesa. Mesmo assim fica claro que os alunos usaram referências do mundo real para construção de seus personagens, ao mesmo tempo adaptando-os para o contexto do RPG.

Esse movimento de referências se assemelha bastante ao conceito de pilhagem narrativa usado por Rodrigues (2004). A autora usa o termo para descrever a apropriação de conceitos, cenários, personagens e estratégias narrativas com o objetivo de aperfeiçoar e até melhorar um produto cultural. Quando analisa o livro de regras do famoso sistema Vampiro: a Máscara, comenta como esse RPG incorpora as mais diversas referências, como os Mandamentos de Moisés, as Tábuas da Lei romanas, as obras de Lovecraft e Edgar Allan Poe. Rodrigues afirma que dialogar com obras de outros autores, de outras épocas, outras mídias é característica intrínseca de um jogo coletivo, instantâneo e oral como o RPG.

Na primeira aplicação do RPG, com os alunos do cursinho, essa pilhagem não foi tão presente, pelo menos não de forma como aconteceu com os estudantes da escola Dona Ana Rosa. Mas ela ainda aparece, como por exemplo o nome do personagem de Gabriel é João das Neves, inspirado no personagem Jon Snow da série de livros/TV Game of Thrones, ou Demitrius, criado por Vinícius, que é claramente inspirado em Ethan Hunt, personagem fictício da série de filmes Missão: Impossível.

Essa etapa do inicial do RPG, onde jogadores desenvolvem a história e características do seu personagem, encaixa bem com os aspectos apontados na literatura sobre dos problemas abertos. Os estudantes usam suas concepções e crenças pessoais quando estão julgando formas de resolver o desafio, que no nosso caso é construir uma personagem original para o jogo.

A primeira sessão termina com cada estudantes declarando as características básicas de seu personagem, como nome, profissão e uma breve história de vida. Peço a eles, após essa etapa, pensarem nos Conceitos dos seus personagens, que é como um resumo, do tamanho de uma frase, dessas características iniciais. Cito como exemplo o Conceito do meu personagem Elon Musk, "Grande empreendedor da tecnologia". Como o tempo acaba, a tarefa fica para a sessão seguinte. Por fim criei um grupo de Whatsapp com os estudantes jogadores e o professor Vitor para trocar informações sobre as futuras sessões, encaminhar o vídeo ${ }^{11}$ produzido para primeira aplicação e também possibilitar que os estudantes mandassem as fotos de suas fichas.

\footnotetext{
${ }^{11}$ Nesta edição foi levemente editado. Está disponível no link https://www.youtube.com/watch?v=jrrFDjYPTSo\&t=10s Acessado em 25/07/2019
} 
A segunda sessão do jogo acontece no dia 17/05 e recomeça com os estudantes terminando de definir os Conceitos e construindo os dois Aspectos dos personagens. O primeiro Aspecto, registra as relações entre as personagens. Os jogadores constroem as seguintes relações: Kyra conheceu Mayers quando cuidou dela e lhe fez o implante do braço. Nessa relação, se apaixonaram. Thanos fora adotado pela mãe de Danielle, e desde de criança quer se vingar de quem matou seus pais. E descobre que o assassino do pai dele é o pai biológico de Danielle. Santos Dumont e Marie Curie tinham ligações secretas. Na infância, Sofia morava com Natasha no mesmo abrigo. Sofia fugiu abandonando a colega gerando uma relação muito ruim entre as duas.

Já o segundo Aspecto registra um defeito do personagem. Apesar desses aspectos serem mais individuais, reforcei aos estudantes que eles discutissem com os colegas os defeitos de seus personagens. Por exemplo Elena determinou White Scale como pouco paciente, Giorgia escolheu Marie Curie como uma pessoa indisposta para fazer tarefas banais e Cristina determinou Sofia como emotiva e ciumenta com Natasha. Por último, escolheram as Façanhas, como explicado em outro capítulo, determina um maior número de sucessos em uma ação dentro do jogo.

Elena: "E se eu quiser colocar um chip na cabeça das pessoas, para saber o que elas estão pensando?"

Essa foi uma das Façanhas debatidas. Elena, criadora de White Scale, queria que a sua hacker tivesse implantado um chip nos outros membros do grupo, para saber como eles pensavam. Essa sugestão de Façanha foi veemente negada por todas. Dei apenas a palavra final, e neguei a Façanha. Assim as escolhas foram acontecendo também com uma discussão entre os alunos. 


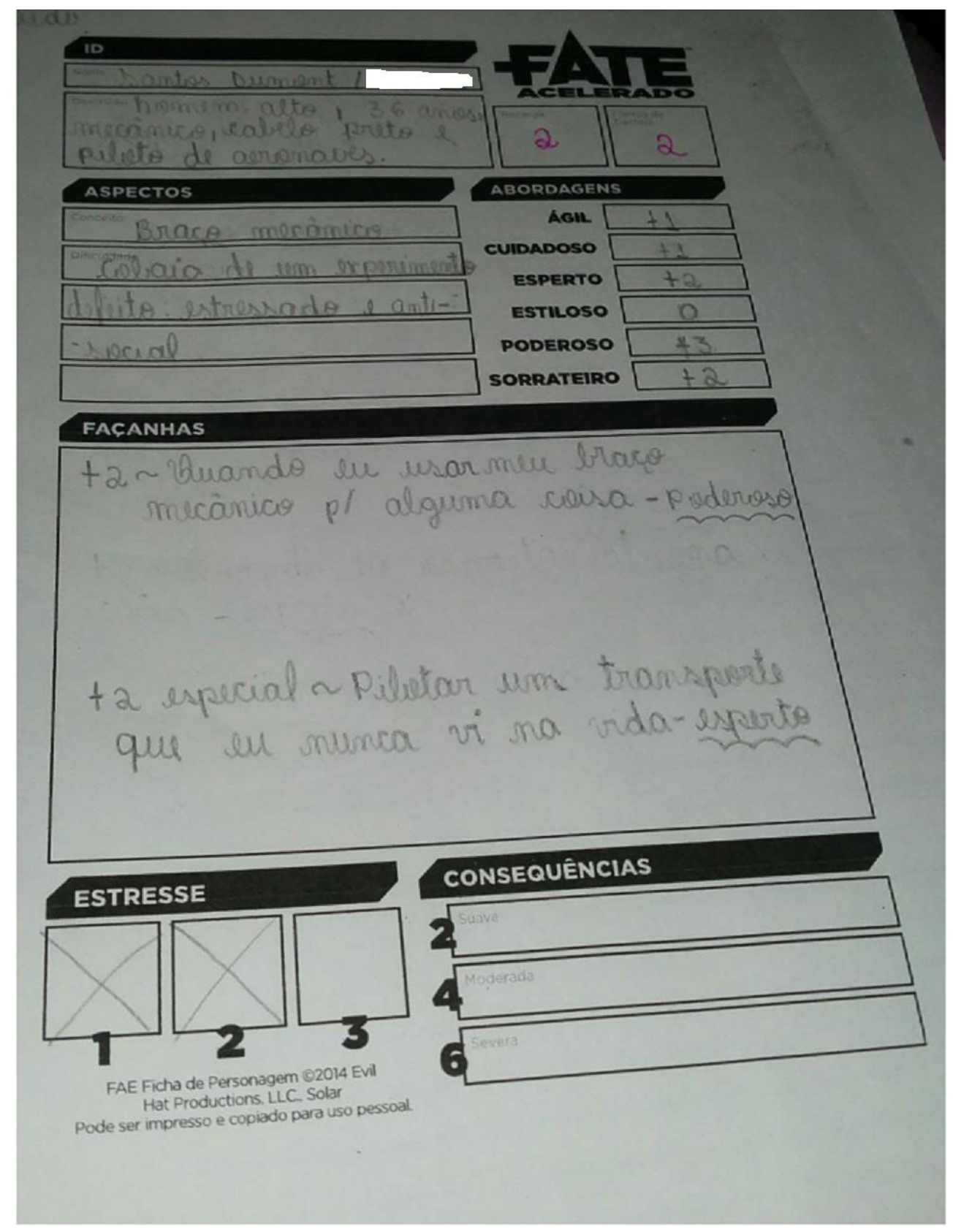

Figura 4: ficha do personagem Santos Dumont da estudante Vanessa.

Com as fichas prontas, começa a aventura e com ela a primeira escolha: qual tipo de nave eles vão. Dou duas opções: uma nave em um formato retangular, com pernas onde os pés são compostos por imãs. Esta nave é apelidada de Sanduíche. A segunda nave, apelidada de Coxinha, tem um formato oval e pés com ventosas. 


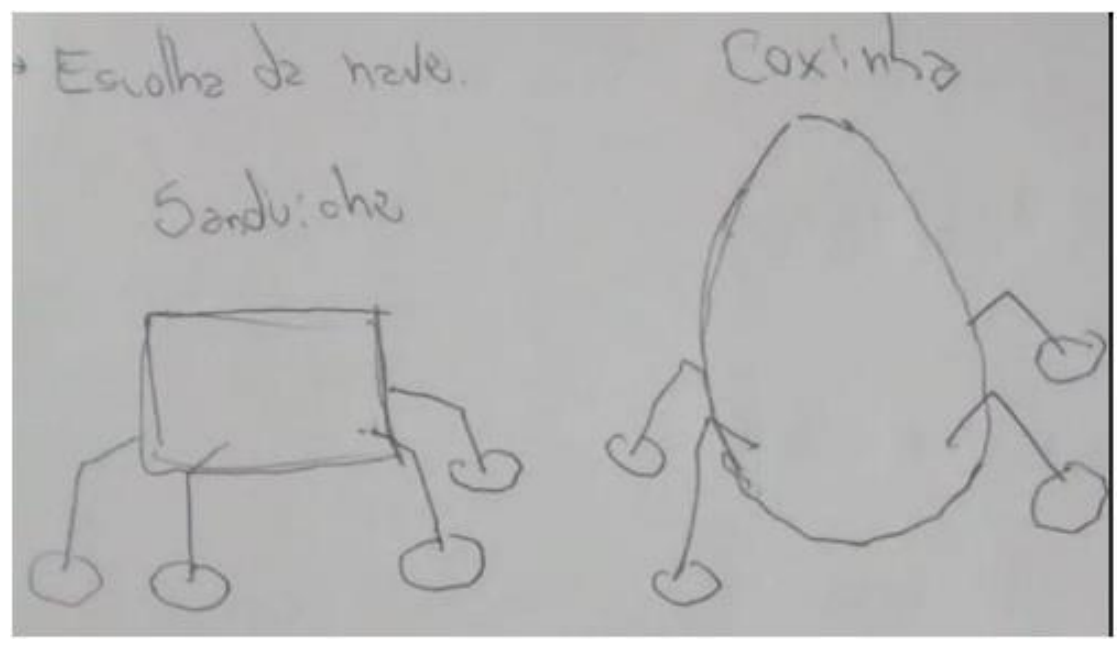

Figura 5: desenho simples das naves, feito pelo mestre para exemplificar aos jogadores

O modelo das naves foi baseado nos módulos lunares do Projeto Apollo 11 americano (sanduíche) e no módulo espacial da nave Soyuz desenvolvido pelo programa espacial soviético (coxinha). Minha ideia era criar um problema aberto para os estudantes resolverem, debatendo qual seria o melhor modelo para pousar em Lovelace. É dito também que a massa da nave sanduíche é dividida homogeneamente, ou seja, o centro de massa está no centro geométrico da nave. Já a coxinha tem o centro de massa mais deslocado para base, como se fosse um joão-bobo. Digo que isso influencia no pouso e consequentemente no sucesso da missão.

Algumas perguntas são feitas pelas estudantes:

Elena: "O peso disso (a nave coxinha) se sustenta por si só?"

Fernanda: "As ventosas seria grudar por pressão?"

Marcelo: O peso da coxinha pode influenciar a trajetória do Lovelace?"

Além dessas questões acima, os estudantes também questionam se o peso concentrado na base da coxinha tornaria mais difícil o retorno do grupo para a Terra. Isso se torna um problema para Giorgia e Denise. Marcelo sugere trocar os pés da Coxinha por imãs, pois existe a suspeita que Lovelace seja uma nave alienígena e, portanto, feita de metal, juntando o melhor dos dois projetos. Alertei sobre a possibilidade do metal que cobria a superfície de Lovelace não ser ferromagnético. 
Diversas discussões paralelas acontecem devido ao problema de escolher a nave. Os estudantes desconfiam das nossas fisionomias - minha e do meu orientador, imaginando que estaríamos rindo por dentro das suas respostas "erradas". Eles esperam chegar na resposta correta. Tento deixar claro que não existe uma resposta "correta" para a escolha da nave e ambas teriam consequências no pouso e na volta para a Terra. Giorgia explícita a ansiedade dos alunos quanto ao resultado:

Giorgia: "Mesmo se a gente não escolhesse certo, daria pra sair de lá (Lovelace)"

Porém mesmo com todas as ideias levantadas, a resolução do enigma de qual nave deve ser usada acaba com uma votação. Após Elena expor que a Coxinha é a melhor opção, pois provavelmente é mais estável.

Elena: "gente o metal tá vindo de outro lugar, então pode ser que os imãs que a gente produziu, não cola, não gruda no metal que eles tem. Não sei se faz sentido como eu tô pensando",

Marcelo: "É o eletromagnético!"

Denise: "Então vamos de coxinha? Quem vota de coxinha?"

Fernanda: Coxinha!

Denise: Coxinha!

Marcelo e as outras meninas ficam em silêncio, como aceitando por consenso. Também aceito o resultado da escolha como a Coxinha e termino a sessão propondo um debate sobre quais itens os estudantes devem levar para a missão. Elena e Marcelo perguntam o que já tem na nave, e se ela possui um banheiro. Fernanda e Giorgia sugerem levar armas, ou armas espaciais - no meu entender armas do futuro, que usam laser ou plasma, opções que são vetadas. Vanessa leva óculos de visão de calor, que pode esquentar objetos emitindo ondas eletromagnéticas.

Narrador: "Vocês também não podem levar nenhum outro ser vivo além de vocês. Tá, quem sabe uma planta." 
Aqui eu poderia ter especificado as condições de transportar outras espécies, pois eles poderiam querer levar também micro-organismos. Além disso, poderia ser proposto um debate sobre a ética de levar outros seres vivos para um ambiente alienígena. Após as escolhas dos itens a serem levados para viagem, acaba a segunda sessão.

Na terceira sessão, que aconteceu no dia 24/05, teoricamente tudo estava certo para a decolagem até Lovelace. Porém, logo no começo do jogo aparecem algumas questões por parte das estudantes. Denise comenta ter visto recentemente em um filme sobre viagem espacial, os astronautas desmaiando quando saiam da atmosfera terrestre, e ela pergunta se isso também aconteceria com os seus personagens. Confesso não ter pensado nesse aspecto sobre a decolagem deles e resolvi incorporar esse fator dentro do jogo, pois me pareceu plausível desmaiar devido a aceleração necessária para atingir a velocidade de escape. Elena também levanta uma questão que é incorporada dentro do jogo:

Elena: "A gente precisa definir o tempo limite para explorar o Lovelace."

Nesse momento eu sigo a estratégia decidida com o prof. André no final da segunda sessão. Quando fizemos uma discussão sobre a sessão, chegamos a conclusão que dali pra frente seria interessante deixar as resoluções dos problemas mais a cargo dos alunos, tentando interferir menos nas discussões. Nesta situação de definir o tempo, eu lanço a pergunta de volta para eles, questionando quais seriam os fatores importantes para definir esse tempo limite. Abaixo segue a transcrição do episódio onde os jogadores debateram sobre o assunto da trajetória e de como seria a aproximação de Lovelace.

Fernanda: "Do tamanho (de Lovelace) e de como a gente vai explorar."

Giorgia: "O solo!"

Elena: "Observar o comportamento. Não de longe, relativamente de perto. Observar o comportamento, as coisas que ele está fazendo. A gente pode seguir o cometa."

Fernanda: "Não é seguir, porque ele está vindo para Terra."

Narrador: "Vocês têm uma previsão da trajetória dele, vocês sabem o caminho que ele vai seguir e vão interceptar ele nesse caminho."

Narrador: "Muito muito rápido." 
Giorgia: "Quanto acelerado?"

Cristina: "Eta gente!"

Narrador: "O que vocês acham que é muito muito rápido?"

Fernanda: "Não era nem pra gente estar demorando pra entrar na nave, né?"

Elena: "Velocidade da luz."

Narrador: "Não, não é tanto assim."

Giorgia: "É menos que o recreio ou mais que o recreio?"

Fernanda: "Muito muito rápido, intervalo daqui."

(risadas)

Narrador: "Se fosse próximo da velocidade da luz, materialmente vocês não conseguiriam chegar perto dele".

Elena: "Então, porque se a gente chegasse perto dele ia dar um impacto. Vai que tipo, sei lá, tivesse uma coisa pra puxar a gente pra baixo, ou pra fazer entrar dentro da..."

Fernanda: "Tipo vai que suga e vruuu."

Narrador: (risadas)

Elena: "Entrar meio que dentro do espaço dele. Daí sei lá."

Narrador: "Não sei se eu entendi."

Elena: "Tipo, como assim, é tipo um planeta. Vamos supor que fosse um planeta, usando esse exemplo, daí tem um espaço aqui em volta que aí quando a gente atravessa essa linha, meio que a gente cai aqui dentro entendeu."

Marcelo: "Seria a atmosfera."

Elena está formulando o problema sobre velocidade relativa e como "entrar" no planeta, sem colidir com ele diretamente. Inicialmente as estudantes respondem à questão de uma forma genérica. E um movimento interessante começou a acontecer nesse episódio: os outros jogadores contribuem não no sentido de elucidar a questão que Elena estava elaborando, mas para tornar claro o enunciado do problema, pois o Narrador não estava entendendo. Diversas tentativas são formuladas pelos jogadores, como Marcelo, que relaciona o problema com a atmosfera, provavelmente porque Elena compara Lovelace com um planeta, e para os estudantes a atmosfera é uma característica importante nos planetas. 
Cristina: "Nossa Elena (incompreensivel) o professor."

Fernanda: "Eu entendi isso da atmosfera que pode ser."

Narrador: "Esse espaço teoricamente seria a atração gravitacional do planeta, certo?"

Elena: "Sim, só que do cometa."

Narrador: "Tipo seria a partir do ponto de onde você não consegue mais escapar dele?"

Elena: "Isso."

Narrador: "É isso? Mas assim isso acontece com corpos muito grandes, né?"

Elena: "Mas ele é muito grande."

Narrador: "Mas não tanto assim. Tipo ele é muito menor que a Lua por exemplo."

Elena: "Ele é menor que a Lua?"

Narrador: "Bem menor, tipo a gravidade dele, que seria a que influencia nisso, do escape dele, é bem menor."

Elena: "Mas é que tipo assim se não tiver uma coisa meio que pra gente chegar e entrar dentro dele, que a velocidade ali é um pouco menor, não sei se você tá entendendo, como se tivesse um escudo em volta dele, dai gente atravessa essa bolha, e a velocidade dentro do que. Por exemplo ele tá caindo e meio que sabe, tá passando um vento por ele, sabe, daí não deixando entrar aqui dentro porque, sei lá."

Giorgia: "Tem uma bolha."

Elena: "Por que se não a gente ia bater nele entendeu, tentando interceptar."

Giorgia: "Bater e destruir a nave."

Havia comentado como Lovelace tinha uma gravidade muito pequena, não tinha atmosfera. Quando Elena começa a explicar sua questão, acreditei que estava falando sobre velocidade de escape, e uma região em volta do cometa de onde eles não poderiam escapar, a não ser usando uma propulsão potente. Mas quando Elena fala sobre o escudo e a diminuição da velocidade, me parece que ela estava falando sobre uma atmosfera, exercendo atrito e diminuindo a velocidade do módulo espacial dos jogadores. Essa confusão sobre a compreensão do problema por minha parte também confundiu os jogadores e dificultou a proposição do problema sobre a velocidade relativa. 
Elena: "É que eu não sei explicar, só tá passando a imagem do que tá acontecendo na minha mente."

Giorgia: "Desenha!"

Fernanda: "Tipo ele pode tá vindo assim e a gente pousar nele e ruuuich".

Narrador: "É isso?"

Elena: "Porque se não a gente vai bater e a gente quer grudar."

Narrador: "Ou vocês querem tipo, a ideia é que vocês."

Fernanda: "A gente quer grudar nele."

Narrador: "É é isso, é vocês".

Cristina: "Grudar só.”

Narrador: "Não baterem de frente com ele, vocês vão tipo."

Cristina: "Aqui assim em cima?"

Giorgia: "Passar por cima e."

Narrador: "Isso, a ideia é que vocês sejam lançados de forma com que vocês."

Cristina: "Fique grudados em cima deles."

Narrador: "Isso, caiam em cima dele."

Giorgia: “Assim... e pá.”

Narrador: "Isso, a ideia eu acho que é essa."

Giorgia e Fernanda tentam constantemente auxiliar Elena a desenvolver o seu problema. Fernanda apoia a hipótese da atmosfera levantada por Marcelo e Giorgia sugere mecanismos para entender o problema, como desenhar. Também suporta a ideia da velocidade relativa, citando a “bolha” comentada por Elena e a preocupação da colisão da nave dos jogadores com Lovelace. Porém acaba se mostrando uma tarefa difícil enunciar esse problema da velocidade relativa, e Giovana expressa que, mesmo com o auxílio dos colegas, não consegue explicar seu pensamento.

Elena: "Tipo como se a gente tivesse daqui pra cá assim, dai ele tivesse vindo pra cá assim (incompreensível)."

(risadas).

Giorgia: "Missão coxinha."

Narrador: "Isso é!" (risadas) 
Cristina: "Parece muito a nossa nave."

Fernanda: "Essa é a nossa nave, a parte dali vai sair."

Giorgia: "Olha gente presta atenção, nossa nave, voando, o cometa que não é um cometa que não é um coiso, nós."

Fernanda: "Um cometa que não deixa de ser um cometa, que não deixa de ser um cometa." Elena: "Tipo assim, ele tá aqui vindo pra cá, sei lá, assim, daí a gente sai daqui, vem pra cá e faz assim...."

Narrador: "Isso, exatamente."

Beatriz: "Que?!"

Narrador: "É é isso aí."

Elena: "Porque se a gente faz uma curva diminui a nossa velocidade, pra cair, com menos, sei lá, não dar tanto impacto e danificar a nave."

Narrador: "Sim, sim."

Cristina: "Gente vocês são muito inteligentes, cara, não dá não."

Fernanda: "Eu, eu só to pensando em como a gente ia ser sugado e tudo, imaginava aqueles vídeo estranho que as coisas parecem ser sólida mas é massinha e entra assime vlaaaa."

Narrador: (risadas)

Giorgia: "E se o negócio não for exatamente pedra, sei lá?"

Alice: "Gente, a gente pode só decolar?”

Narrador: "Sim, mas isso vocês só vão conseguir identificar lá."

Fernanda: "Vamo na fé de meu deus, vamo decolar lá."

Giorgia: "E se for uma gelatina gigante?"

Elena: "Vai então vamos definir a trajetória."

Fernanda: "Éééé, acabou, o cometa chegou na Terra, ficamos muito tempo sem decolar (risadas) morremos!”

Giorgia: "Acabou nosso treinamento."

Beatriz: "Vocês complicam demais, complicam o assunto."

(conversas incompreensíveis) 
Em toda a discussão sobre o pouso em Lovelace fica clara a centralidade da comunicação no diálogo entre o narrador e Elena. Acreditava que a discussão seria interessante, tanto para o jogo quanto para o aprendizado de física. Porém esta centralidade afastou alguns jogadores. Beatriz, estando alheia a discussão, expressa sua inconformidade ao ver que ela estava sendo encaminhada para uma resolução, porém não estava compreendendo as discussões. Os outros jogadores, que não estavam participando da tentativa de elaboração do problema, talvez por não conseguirem criar uma relação significativa com os temas abordados, pedindo para voltarmos ao jogo em si. Aline, por exemplo, pede para deixarmos essa discussão de lado e partir para a decolagem dos jogadores em direção ao cometa. Essa urgência pela volta ao jogo está relacionada com um aspecto importante de como os problemas surgem e são resolvidos dentro do jogo.

Narrador: "Beleza."

(conversas paralelas, não é possível identificar o assunto)

Narrador: "Tá, o que que a gente, o que que a gente chegou no consenso até agora?"

Giorgia: "O consenso é que, nois vai, nos vai."

Fernanda: "Nós vai morrer!"

Elena: "Que nós escolhemos a nave, nós estamos preparados."

Narrador: "Isso."

Elena: "Já definimos os objetos."

Narrador: "Já definiram os objetos?"

Giorgia: "Nós vamos sair de onde mesmo? Do Maranhão onde?"

Narrador: "Isso, Alcantara."

Elena: "A gente já definiu a localização da nossa base de?"

Narrador: "Lançamento."

Elena: "De lançamento."

Giorgia: "Alcan..."

Narrador: “Tara.” (completando a fala anterior da Giorgia)

Elena: "Agora a gente tem que definir a trajetória da nossa nave para chegar lá." Narrador: "Beleza, como vocês definiriam essa trajetória?”

Elena: "Ah eu definiria assim, tipo a gente tá aqui (gesticulando para indicar)." 
Fernanda: "E o que que a gente vai fazer quando a gente chegar lá. Tipo, quem vai sair, como que vai sair."

Narrador: "Tipo, o que que é importante pra pensar na trajetória?”

Giorgia: "Saber onde o cometa está exatamente localizado antes da gente sair daqui, onde a gente está."

Narrador: "Importante, vocês sabem."

Giorgia: "Eles estão, tipo a gente está aqui no Maranhão enfim, e em qual localização o cometa ou asteroide tá vindo."

Elena: "Sim porque a gente precisa fazer o cálculo do tempo, por exemplo..."

Fernanda: "Que a gente vai levar pra chegar lá."

Elena: "E a gente precisa calcular o ponto que a gente vai encontrar com ele."

Giorgia: “O tempo que a gente vai levar.”

Elena: "Então a gente precisa calcular esse tempo, pra poder planejar o tempo da nossa viagem, pra conseguir chegar lá a tempo."

É possível observar que apesar de o RPG parecer um ambiente propício para o surgimento de novos problemas, o caráter lúdico permite saídas fáceis para a resolução, apelando para as regras do jogo ou continuação da narrativa da história. O problema levantado por Elena acabou sem resolução e foi abandonado pelos jogadores. Esquecê-lo em troca de continuar a história do jogo, acabou se tornando uma solução, fugindo da expectativa do resultado de um problema aberto. Através da análise desse episódio, é possível perceber algum dos limites da aplicação de um RPG com contexto educativo.

Ao meu ver essa discussão mostra mais um exemplo de como os alunos usam suas referências pessoais e conhecimentos para abordar este problema aberto. Elena, formulou a questão e os outros jogadores estão usando os conhecimentos de física para pensar o problema. Apesar de não resolverem o problema explicitamente usando conhecimentos físicos, os conceitos para pensar essa questão da posição e do tempo limite para explorar Lovelace são científicos. O chute da velocidade da luz por Elena mostra o que ela entende pela maior velocidade do universo, no entanto ela desconsidera o fato da velocidade da luz não poder ser atingida por nenhum corpo celeste conhecido. 
Ainda na terceira sessão, Elena levanta o problema da temperatura que eles ficariam submetidos quando pousarem em Lovelace.

Mestre: "Vocês acham que teria como analisar o solo de lá?"

Fernanda: "Tem. A gente colhe o material e leva pra nave."

Elena: "E se tiver muito quente pra gente sair fora da nave?"

Fernanda: "A gente volta e aguarda a morte né cara."

Elena: "A gente não sabe a temperatura de lá. a gente não sabe..."

Fernanda: "E se a nave tiver um bagulho que analisa temperatura?"

Giorgia: "A gente faz uma roupa térmica. uma roupa pra aguentar o calor e o frio."

Elena: "Legal."

Giorgia: "A gente pode incorporar as duas roupas em uma só”.

Fernanda: "É uma roupa que se adapta ao clima de lá."

Narrador: "Então o que vocês querem fazer é: uma forma de saber a temperatura de fora (da nave dos jogadores) e vocês terem uma roupa adequada pra sair certo?"

Giorgia: "A gente tá tentando incorporar as duas roupas em uma só. Fazer com que essa roupa aguente tanto o calor e o frio."

Narrador: "E aí, vocês acham que dá pra vocês fazerem isso?"

Fernanda: "Acho que sim."

Giorgia: "Acho que dá."

Elena: "Claro que dá."

Narrador: "Como então?”

Giorgia: "É tipo quando a gente leva uma marmita. Coisa quente ele mantem quente. Coisa fria ele mantém fria."

Elas tentam perguntar para o professor Vitor que está na sala, mas ele não responde, talvez para não interferir no jogo, ou para deixar as jogadoras pensarem mais na questão. Tinha autorizado os estudantes fazerem perguntas para o professor, funcionando como um "Google" para eles. Pergunto se tem algo no dia a dia deles que tem essa função, de se adaptar ao ambiente, como Elena estava comentando. Alice comenta sobre a bolsa térmica exercer essa função. Alguém, que não consigo identificar comenta sobre a garrafa térmica. Fernanda e Giorgia comentam sobre a cor 
da roupa, pois preto absorve calor e o branco seria para refletir o calor, então seria necessário conciliar essas propriedades. Elena fala que não pode ser preto porque se não eles vão queimar.

Giorgia: "E se estiver muito frio lá? Você vai precisar absorver energia. E energia é calor."

Cristina: "Não era para eu estar aqui. Vocês são muito inteligentes."

A fala de Cristina explicita que nem todos estavam confortáveis com as discussões ocorridas durante o jogo. Cristina e Beatriz constantemente falavam coisas como "vamos para o jogo", "estamos demorando muito". Outros jogadores não se manifestam por um longo período dentro da sessão, como Vanessa, Denise e Marcelo. Essa tensão entre o jogo e as discussões paralelas aos jogos se intensifica com o decorrer das sessões, o que meu ver atrapalhou a segunda aplicação. Alguns alunos ficam entediados com o alongamento das discussões e acabam se dispersando da história. No começo da sessão eu estava com o intuito de promover as discussões entre os estudantes, mas isso acabou tendo efeitos negativos.

Após pousarem em Lovelace, eles se separam em dois grupos: um ficou na nave monitorando o segundo grupo foi investigar o cometa. Esse foi outro problema que contribuiu para dispersão dos alunos. Quando estava narrando as cenas referentes a um grupo, os integrantes do outro grupo as vezes ficavam entediados e deixavam de acompanhar a história. Esse tédio culminou em uma votação na quarta sessão para voltar para Terra e abandonar o problema que era Lovelace. Isso aconteceu quando o segundo grupo conseguiu chegar até a "gaveta com agulhas" e a porta com símbolos luminosos. Os jogadores não entenderam como uma entrada, e as agulhas como um mecanismo de análise de seus objetos, e decidiram voltar para a coxinha, e em seguida voltar para casa. Nesse momento eles perderam o engajamento.

Como forma de reverter a situação, enviei uma mensagem de socorro contida numa memória digital, flutuando no líquido da superfície de Lovelace. Essa mensagem foi decifrada por Elena. A mensagem continha uma planta/mapa de Lovelace e uma indicação, meio de sinais e setas, como eles poderiam entrar na nave. A partir daí, o cenário teve uma mudança drástica, e eu tive que mudar toda a estrutura da nave, como foi comentado no capítulo 4. Na quinta e na sexta sessões surgiram poucas questões referentes à física. 
Ainda na quarta sessão Elena propôs uma estratégia de movimentação até a entrada da nave sem passar pelo fluído. Sua hipótese era sair da superfície do cometa, esperar ele rotacionar, e depois pousar de volta no lugar necessário. Esse comentário está muito baixo nos áudios e eu não ouvi enquanto estava narrando. O professor Vitor, comentou isso comigo depois que a sessão tinha acabado. Essa hipótese levantada por Elena era uma ótima abertura para se discutir o conceito de inércia, porém ela foi desperdiçada. Esse infortúnio tem relação com outro fator que comprometeu a segunda aplicação: um número elevado de jogadores.

Inicialmente o projeto foi estruturado com dois grupos, com no máximo 5 estudantes cada, no caso de 10 voluntários contemplados, o limite estipulado na pesquisa. Esse limite foi decidido baseando-se num grupo de RPG tradicional que geralmente flutua entre 4 e 6 jogadores. O livro de regras do sistema Fate, utilizado para construir a aventura, recomenda de três a cinco pessoas. (HICKS, 2013)

Por incompatibilidade com as datas das sessões e com o uso do espaço da escola, mas que a pesquisa continuasse mesmo assim, foi formado apenas um grupo com os 9 estudantes. $O$ número elevado comprometeu as discussões e o engajamento dos alunos. E quando eles se separaram depois do pouso, ficou mais difícil de mantê-los engajados nas discussões e resoluções dos problemas da nave.

Apesar das dificuldades foi uma experiência muito proveitosa. O RPG se mostrou um ótimo ambiente para se conhecer as concepções dos estudantes sobre diversos conceitos de Física e também foi interessante notar que eles conseguem elaborar hipóteses baseando-se em conteúdos aprendidos em sala de aula. Os debates durante o jogo geralmente levantam diversas hipóteses interessantes de serem discutidas e abordadas como um desafio dentro do próprio jogo. Mas se faz necessário um balanço constante entre o jogar e o discutir, pois pode acontecer de alguns estudantes se absterem ou ficarem entediados com o tema, o que faz eles perderem o interesse no problema, retirando uma das características principais dos problemas abertos. 


\section{Considerações finais}

O presente estudo partiu da premissa de unir dois temas de pesquisa: a aplicação do RPG num contexto educacional e o uso de problemas abertos no ensino de física. O objetivo era investigar como o RPG pode ser jogado por estudantes, observando como eles lidam com os problemas que surgem durante as sessões da aventura.

Foi constatado que os estudantes expõem suas visões e concepções sobre diversos conceitos físicos durante o jogo. Como velocidade, gravidade, como funcionam os ímãs e a transmissão de ondas eletromagnéticas. Assim, ao meu ver, o RPG é uma maneira eficaz de verificar a compreensão dos alunos sobre temas da física, auxiliando a construir novos problemas, qualidade importante na problematização como apontado por Delizoicov. Essas observações podem ser bases para formular problemas significativos para esses estudantes e assim colocar o conhecimento em movimento, onde novos conhecimentos geram novas concepções, formando a base para outras questões.

Quanto aos problemas abertos, foi observado que os estudantes se engajam na resolução dos problemas que aparecem durante o jogo, e usam conceitos físicos para delimitar o problema e elencar as variáveis dependentes para encontrar uma solução. Ou seja, a investigação dos alunos ao meu ver, passa pelo aprendizado físico e mobiliza diversos conhecimentos. Além disso os próprios estudantes pensam problemas que não estavam previstos anteriormente, como Cristina problematizando a reação do organismo humano devido a aceleração da nave para partir da Terra, ou Vinícius que criou uma problematização sobre a rotação do cometa na primeira aplicação. Porém isso não ocorreu quando chega o momento de executar a resolução de fato.

Os estudantes usam majoritariamente mecanismos oferecidos pelo jogo, como a rolagem de dados para encontrar a solução propriamente dita, por exemplo quando os jogadores usaram a rolagem de dados para saber se tinham sucesso no cálculo da trajetória e velocidade necessárias para que eles chegassem na nave dentro do tempo limite ou para a confecção das roupas térmicas. Ou ainda, usam recursos que se encontram no RPG, mas não na investigação científica, como a votação entre os estudantes da segunda aplicação, para determinar qual seria o módulo usado para pousar em Lovelace. Esse caráter não se constitui numa característica prejudicial em si, mas é 
importante os estudantes também pensarem resoluções de uma forma mais parecida com a estruturada pela ciência.

A partir dessa ideia pode-se elencar algumas hipóteses para uma possível nova aplicação do RPG no contexto educacional. Os estudantes poderiam realizar algumas tarefas, ou resolver algum problema relativo ao jogo, entre as sessões. O jogo serviria para criar significado para as questões, que seriam propostas no final da sessão, para serem resolvidas e suas respostas serem usadas na sessão seguinte, como uma forma de pesquisa ou preparação para o próximo encontro. Inclusive uma dessas questões poderia ser um problema de lápis e papel. Essas questões de pesquisa podem ser delegadas também aos estudantes que estão esperando o outro grupo agir, caso os jogadores se separem.

Porém é importante ter em mente evitar que os jogadores se separem. Manter um grupo que faça as ações sempre em conjunto facilita o trabalho como narrador, e impede que os jogadores fiquem muito tempo esperando por suas rodadas. Conhecer os alunos previamente também ajuda bastante no jogo. No jogo piloto, que fiz com estudantes que já conhecia, as sessões aconteceram com maior fluidez, e esse aspecto dificultou um pouco o andamento do jogo na segunda aplicação. Como o RPG é um jogo de conversa constante, conhecer os jogadores e o seu repertório das aulas de física auxilia o desenvolvimento das sessões, e impede que se esgotem as possibilidades de discussão.

No podcast \#325 - Estudos sobre RPG e educação ${ }^{12}$, o pesquisador Luiz Eduardo Ricon, escritor de Desafio dos Bandeirantes, um famoso RPG com temas baseados na História e no folclore brasileiros, faz um comentário interessante sobre o uso de RPG na escola. Ele comenta que nesse processo "ou muda-se o RPG ou muda-se a escola". Isso significa que se deve jogar o RPG com estudantes nos moldes mais tradicionais e alterando a estrutura da escola, ou alterar o formato do jogo para manter a configuração original das aulas. Essa alteração na estrutura escolar pode ser no horário, com as sessões sendo realizadas no contraturno ou fora do horário de aula, ou até alterar a elaboração do currículo da escola para contemplar o uso dos jogos de forma educativa.

\footnotetext{
${ }^{12}$ Disponível no link https://regradacasa.podbean.com/e/325-estudos-sobre-educacao-e-rpg/ acessado em $27 / 07 / 2019$
} 
Caso opte-se alterar o RPG, o pesquisador ou professor que irá usar o recurso lúdico, pode mudar as regras, ou mesmo a estrutura do jogo, como o júri simulado estudado por Sabka (2016).

Se a opção for manter o RPG mais próximo da versão não educacional, é importante levar em consideração o número de alunos participantes, como mencionado acima e também se preocupar com o engajamento dos alunos e manter o foco deles na história. Um recurso que pode ser usado é utilizar de abundantes recursos visuais, como desenhos e mapas, e representações da história que está sendo construída.

Como finalização, acredito comentar duas questões que acredito serem importantes, mas não houve tempo suficiente para discuti-las nesta pesquisa. A primeira é a contradição que existe entre a obrigatoriedade do ensino e o caráter voluntário do jogo. Segundo Huizinga o jogo deve ser livre de qualquer imposição física e moral, portanto em disparidade com a obrigatoriedade do ensino. Portanto é interessante, em propostas não só de RPG, como qualquer jogo, voltadas ao ensino esse conflito e como encontrar maneiras de executar a conciliação entre a voluntariedade do jogo e a educação obrigatória.

A segunda questão é referente a diversão. Quando comecei essa pesquisa não tinha ideia da dimensão das pesquisas sobre jogo e ensino de ciências. Pode-se dizer sem medo que é um campo bem fundamentado. Depois de participar de um congresso ${ }^{13}$ e um curso de extensão ${ }^{14}$ sobre o assunto, observo que além de sólido, essa área de pesquisa já tem algumas concepções estabelecidas. Uma delas é que qualquer jogo utilizado na escola deve ser no mínimo divertido. É a fundação do projeto. Por isso, a regra de ouro sobre pesquisar e aplicar jogos para estudantes da educação básica, é utilizar um jogo que seja divertido para os estudantes. Sem a diversão não existe nada.

\footnotetext{
${ }^{13}$ JALEQUIM III - ENCONTRO NACIONAL DE JOGOS E ATIVIDADES LÚDICAS NO ENSINO DE QUÍMICA, FÍSICA E BIOLOGIA (2018)

${ }^{14}$ Jogos Educativos para Ciências Naturais no Ensino Médio - Instituto Federal campus São Paulo. (2019)
} 


\section{Referências}

AMARAL, R. O uso do RPG pedagógico para o ensino de física. 2008. 170f. Dissertação (Mestrado em Ensino das Ciências) - Universidade Federal Rural de Pernambuco, Recife. 2008.

AMARAL, R.; BASTOS, H. F. B. N. O Roleplaying Game na sala de aula: uma maneira de desenvolver atividades diferentes simultaneamente. Revista Brasileira de Pesquisa em Educação em Ciências, v. 11, n.1, 2011.

BRASIL. Orientações Educacionais Complementares aos Parâmetros Curriculares Nacionais (PCN+). Ciências da Natureza e Matemática e suas tecnologias. Brasília: MEC, 2006.

CLARKE, A. C. Encontro com Rama. São Paulo: Aleph, 2010. 286p.

CLEOPHAS, M.; CAVALCANTI, E.; SOARES, M. Afinal de Contas, é Jogo Educativo, Didático ou Pedagógico no Ensino de Química/Ciências? Colocando os Pingos nos "is". In: Cleophas, Maria; Soares, Márlon (orgs.). Didaditazção Lúdica no Ensino de Química/Ciências: Teorias de Aprendizagem e Outras Interfaces. São Paulo: Editora Livraria da Física, 2018.

DELIZOICOV, D. Problemas e problematizações. In: Maurício Pietrocola. Ensino de Física: Conteúdo, metodologia e epistemologia em uma concepção integradora. $2^{a}$ Ed. Ilhéus: Ed. da UESC.

ELKONIN, D.B. Psicologia do Jogo. São Paulo: Martins Fontes, 1998. 447p.

FAIRCHILD, T. O discurso de escolarização do RPG. 2004. 165f. Dissertação (Mestrado em Educação). Faculdade de Educação da Universidade de São Paulo, São Paulo. 2004.

HEWITT, P.G. Física Conceitual. Porto Alegre: Bookman, 2002.

HICKS, F. Fate Sistema Básico. Londrina: Solar Entretenimento, 2015. 300p. 
LABURU, C.; ARRUDA, S.; NARDI, R. Pluralismo metodológico no ensino de ciências. Ciênc. educ. (Bauru), Bauru, v. 9, n. 2, p.247-260, 2003. Disponível em http://www.scielo.br/scielo.php?script=sci_arttext\&pid=S1516$73132003000200007 \& \operatorname{lng}=$ en\&nrm=iso. Acessado em 23 de julho de 2019.

MARCATTO, A. Saindo do Quadro: Uma Metodologia Educacional Lúdica e Participativa baseada no Role Playing Game. São Paulo: Exata Comunicação e Serviços S/C LTDA. 1996. $185 \mathrm{p}$.

NASCIMENTO JR., F.; PIASSI, L.P.; RAMOS, J.E.F. O Potencial de Aplicação de aventuras de RPG no Ensino de Física. In: II Simpósio Nacional de Ensino de Ciência e Tecnologia, 01, 2010, Curitiba.

NASCIMENTO, R. O. Um estudo sobre o pensamento na resolução de problemas segundo contribuições de Sergei L. Rubinstein: aportes psicológicos para a educação do pensamento. Obutchénie: Revista de Didática e Psicologia Pedagógica. Uberlândia, v. 1, n. 22, p. 411-431, mai/agos. 2017.

OLIVEIRA, Vagner; ARAUJO, Ives Solano; VEIT, Eliane Angela. Resolução de problemas abertos no ensino de física: uma revisão da literatura. Revista Brasileira de Ensino de Física. São Paulo, v. 39, n. 3, e3402, 2017.

PEDUZZI, Luiz Orlando de Quadro. Sobre a resolução de problemas no ensino da Física. Caderno Brasileiro de Ensino de Física, Florianópolis, v. 14, n. 3, p. 229-253, jan. 1997. ISSN 2175-7941. Disponível em: 〈https://periodicos.ufsc.br/index.php/fisica/article/view/6982>. Acesso em: 14 out. 2019. doi:https://doi.org/10.5007/\%x.

PÉREZ, Daniel Gil et al. Questionando a didática de resolução de problemas: elaboração de um modelo alternativo. Caderno Brasileiro de Ensino de Física, Florianópolis, v. 9, n. 1, p. 7-19, jan. 1992. 
RODRIGUES, B. C. Corrida vetorial em aulas de Física. 2013. 225f. Dissertação (Mestrado em Ensino, História e Filosofia das Ciências e Matemática) - Universidade Federal do ABC, Santo André, 2013.

RODRIGUES, S. Roleplaying Game e a Pedagogia da Imaginação no Brasil. Rio de Janeiro: Bertrand Brasil, 2004. 204p.

SABKA, D. Uma abordagem CTS das máquinas térmicas na revolução industrial utilizando o RPG como recurso didático. 2016. 132f. Trabalho de Conclusão (Mestrado em Ensino de Ciências) - Universidade Federal do Rio Grande do Sul, Porto Alegre. 2016.

SCHMIT, W. L. RPG e Educação: alguns apontamentos teóricos. 2008. 267f. Dissertação (Mestrado em Educação) - Universidade Estadual de Londrina, Londrina, 2008.

SILVA, P.H.S. O Role-playing game (Rpg) como ferramenta para o ensino de Física. 2016. 129 f. Dissertação (Mestrado em Ensino de Ciências) - Instituto de Física. Universidade Federal do Rio de Janeiro, Rio de Janeiro. 2016.

SOARES, M. H. F. B.; GARCEZ, E. F. C. Um Estudo do Estado da Arte Sobre a Utilização do Lúdico em Ensino de Química. Revista Brasileira de Pesquisa em Educação em Ciências, v.17, n.1, p. 184-214, abril 2017.

STETSENKO, A.; HO, P. G. The Serious Joy and the Joyful Work of Play: Children Becoming Agentive Actors in Co-Authoring Themselves and Their World Through Play. International Journal of Early Childhood, v.47, n.2, p. 221-234, agosto 2015.

VASQUES, R. As potencialidades do RPG na educação escolar. 2008. 179f. Dissertação (Mestrado em Educação Escolar) - Faculdade de Ciências e Letras. Universidade Estadual Paulista, Araraquara. 2008.

ZYLBERSZTAJN, A. Resolução de problemas: uma perspectiva Kuhniana. In: Encontro de Pesquisa em Ensino de Física, 6., 1998, Florianópolis. Anais... Florianópolis, 1998. 1 CD 